\title{
Copper uptake, accumulation and physiological changes in adult grapevines in response to excess copper in soil
}

\author{
Alcione Miotto - Carlos A. Ceretta - Gustavo Brunetto • \\ Fernando T. Nicoloso • Eduardo Girotto • Júlia G. Farias • \\ Tadeu L. Tiecher • Lessandro De Conti • Gustavo Trentin
}

Received: 12 December 2012 / Accepted: 23 August 2013 /Published online: 24 September 2013

(C) The Author(s) 2013. This article is published with open access at Springerlink.com

\begin{abstract}
Aims This study investigated $\mathrm{Cu}$ uptake and accumulation as well as physiological and biochemical changes in grapevines grown in soils containing excess $\mathrm{Cu}$.

Methods The grapevines were collected during two productive cycles from three vineyards with increasing concentrations of $\mathrm{Cu}$ in the soil and at various growth stages, before and after the application of $\mathrm{Cu}$-based fungicides. The $\mathrm{Cu}$ concentrations in the grapevine organs and the macronutrients and biochemical parameters in the leaf blades were analyzed.
\end{abstract}

Responsible Editor: Yong Chao Liang.

A. Miotto • C. A. Ceretta $(\bowtie) \cdot$ G. Brunetto • T. L. Tiecher

L. De Conti

Departamento de Ciência do Solo,

Universidade Federal de Santa Maria,

97105-900 Santa Maria, RS, Brazil

e-mail: carlosceretta@ufsm.br

A. Miotto

e-mail: alcionemiotto@gmail.com

F. T. Nicoloso $\cdot$ J. G. Farias

Departamento de Biologia, Centro de Ciências Naturais

e Exatas, Universidade Federal de Santa Maria,

Santa Maria, RS 97105-900, Brazil

E. Girotto

Instituto Federal de Educação,

Ciência e Tecnologia do Rio Grande do Sul,

Ibirubá, RS 97105-120, Brazil

G. Trentin

Embrapa Pecuária Sul,

Bagé, RS 96401-970, Brazil
Results At close to the flowering stage of the grapevines, the concentration and content of $\mathrm{Cu}$ in the leaves were increased. However, the $\mathrm{Cu}$ concentrations in the roots, stem, shoots and bunches did not correlate with the metal concentrations in the soil. The application of $\mathrm{Cu}$-based fungicides to the leaves increased the $\mathrm{Cu}$ concentrations in the shoots, leaves and rachis; however, the effect of the fungicides on the $\mathrm{Cu}$ concentration in the berries was not significant. The biochemical analyses of the leaf blades demonstrated symptoms of oxidative stress that correlated with the $\mathrm{Cu}$ concentrations in soil.

Conclusions The increased availability of $\mathrm{Cu}$ in soil had a slight effect on the levels and accumulation of $\mathrm{Cu}$ in mature grapevines during the productive season and did not alter the nutritional status of the plant. However, increased $\mathrm{Cu}$ concentrations were observed in the leaves. The evidence of oxidative stress in the leaves correlated with the increased levels of $\mathrm{Cu}$ in soil.

Keywords Heavy metals · Plant nutrition - Oxidative stress $\cdot$ Copper-based fungicides $\cdot$ Vineyard

\section{Introduction}

Copper $(\mathrm{Cu})$-based fungicides, such as the Bordeaux mixture $\left[\mathrm{CuSO}_{4} \cdot 5 \mathrm{H}_{2} \mathrm{O}+\mathrm{Ca}(\mathrm{OH})_{2}\right]$, are applied in vineyards to control fungal diseases such as mildew (Plasmopara viticola). These fungicides are inexpensive and efficient at controlling diseases, and they demonstrate low toxicity in plants. Therefore, these fungicides are often used in vineyards, including organic vineyards 
(Council Regulation 2092/91/EEC 1991). However, the successive application of fungicides increases the total and available $\mathrm{Cu}$ in the soil (Brun et al. 2001; Pietrzak and McPhail 2004; Fernández-Calviño et al. 2009), reaching high and even excessive concentrations for the plants. The excessive accumulation of $\mathrm{Cu}$ in the soil in vineyards is a major environmental problem because it occurs over large areas in many countries (Komárek et al. 2010). Excessive $\mathrm{Cu}$ can affect the biological activity of soils (Dumestre et al. 1999), in that it is toxic to plants (Brun et al. 2003; Chaignon and Hinsinger 2003), it is leached into the soil profile, and it pollutes groundwater (Robinson et al. 2006). In enriched sediments, the $\mathrm{Cu}$ can be transferred to surface water through runoff (Fernández-Calviño et al. 2008).

Copper is a micronutrient in plants and functions in conjunction with a large number of enzymes related to respiration and photosynthesis (Marschner 1995; Yruela et al. 2000). The main visual symptoms of excess $\mathrm{Cu}$ are the impaired growth of the roots and shoots, nutrient deficiency, chlorosis, and, in more severe cases, tissue necrosis and plant death (Marschner 1995; Kopsell and Kopsell 2007). These symptoms are caused by the direct and indirect action of the $\mathrm{Cu}$ in plants. The reduction in the growth of the roots results in less exploration of the soil by the roots. This aggravates damage to the cell membranes in the roots (De Vos et al. 1989) and results in a significant decrease in the uptake of nutrients and water (Kopsell and Kopsell 2007). The effect of $\mathrm{Cu}$ toxicity in the roots is reflected in indirect symptoms, such as the reduction of branch growth and the chlorosis caused by the generalized deficiency of nutrients and water (Marschner 1995; Yruela et al. 2000). A direct effect of high $\mathrm{Cu}$ concentrations at the cellular level is oxidative stress caused by the increased concentration of reactive oxygen species (ROS), such as superoxide anion $\left(\mathrm{O}^{2--}\right)$, singlet oxygen $\left({ }^{1} \mathrm{O}_{2}\right)$, hydrogen peroxide $\left(\mathrm{H}_{2} \mathrm{O}_{2}\right)$ and hydroxyl radical $\left(\mathrm{OH}^{-}\right)$(Apel and Hirt 2004). ROS can damage all biomolecules; however, lipid peroxidation of the cell membranes is one of the most important effects observed. Damage to the cell membranes results in lower selectivity and eventually causes membrane breakage and leakage of the cell contents (De Vos et al. 1989; Yruela 2005).

Studies have been performed on vineyard soils to assess $\mathrm{Cu}$ availability and the effect of excess $\mathrm{Cu}$ on plant nutrition. Studies using chemical extractors demonstrated that $\mathrm{Cu}$ availability is higher in acid and sandy soils containing low concentrations of organic matter (Brun et al. 2001; Chaignon and Hinsinger 2003; Pietrzak and
McPhail 2004; Arias et al. 2005). However, estimations of the total concentration of $\mathrm{Cu}$ in the soil (or the amount of $\mathrm{Cu}$ extractable using various methods) are ineffective for predicting the $\mathrm{Cu}$ absorption and its toxicity to plants (Brun et al. 1998). Therefore, studies have investigated plants to assess the $\mathrm{Cu}$ availability in soils (Brun et al. 2003; Chaignon et al. 2009). Although the cultivation of grapevines is often associated with the use of fungicides, few studies have used grapevines for the investigation of $\mathrm{Cu}$ availability and toxicity.

The effects of excessive $\mathrm{Cu}$ in soils on the nutrition of grapevines are unclear. Young grapevine plants grown in soils newly contaminated with $\mathrm{Cu}$ demonstrate reduced growth in the roots and shoots, leaf chlorosis and $\mathrm{Cu}$ accumulation in the roots. However, a small amount of $\mathrm{Cu}$ is translocated to the branches (Toselli et al. 2009). In contrast, adult grapevines during the productive season do not exhibit visual symptoms of toxicity caused by $\mathrm{Cu}$ but can uptake and accumulate $\mathrm{Cu}$ in the perennial and annual organs (Lai et al. 2010).

Grapevines remain productive for decades in soils with high $\mathrm{Cu}$ concentrations, and the plants are often subjected to spraying with $\mathrm{Cu}$-based fungicides. The uptake of $\mathrm{Cu}$ from the soil and from the $\mathrm{Cu}$-containing fungicide sprayed directly on the aerial parts of the plant represent two sources of this metal for the plant. Under conditions of high levels of $\mathrm{Cu}$ in the soil and the spraying of $\mathrm{Cu}$-based fungicides, grapevines can exhibit the increased uptake and accumulation of $\mathrm{Cu}$ and toxicity symptoms of excessive $\mathrm{Cu}$ in the tissues. In addition, $\mathrm{Cu}$ accumulation in the roots may affect the uptake of other nutrients, causing nutritional problems for the plants. This study evaluated the concentration and content of $\mathrm{Cu}$ in the plant organs and the physiological and biochemical changes in the leaf blades of mature plants during the productive season in grapevines grown in soils with increasing $\mathrm{Cu}$ levels.

\section{Material and methods}

\section{Research locality}

The study was performed in vineyards located in the municipality of Santana do Livramento (Rio Grande do Sul State, Brazil). The climate is subtropical, classified as Cfa (Köppen classification), with an average rainfall of $1,388 \mathrm{~mm}$ year $^{-1}$ (IPA 1989). The three vineyards of the variety Cabernet Sauvignon (Vitis vinifera) grafted on 
rootstock SO4 (Vitis berlandieri $x$ Vitis riparia) were used in the experiments. Vineyard 1 (VN1) was planted at a density of 2,778 plant ha ${ }^{-1}$ in 2004 (S 30 46 $46^{\prime} 1^{\prime \prime}, \mathrm{W}$ $55^{\circ} 22^{\prime} 34^{\prime \prime}$ ); vineyard 2 (VN2) was planted at a density of 2,525 plant ha $^{-1}$ in 1998 (S 3047'44", W 55²1'56"); and vineyard 3 (VN3) was planted in 1977 at a density of 1,429 plant ha ${ }^{-1}$ (S 30 46'36", W 55 22'03"). The vineyards were developed using the vertical shoot position training system with heavy pruning and fertilization with nitrogen $(\mathrm{N})$, phosphorus $(\mathrm{P})$ and potassium $(\mathrm{K})$, performed equally for each vineyard. The control of fungal foliar diseases was performed preventively, including the use of Cu-based fungicides, only after the formation of the berries. In the vineyards, the 2009/2010 and 2010/2011 cycles were assessed. The phenological stages evaluated in the two cycles and the amounts and timing of the application of the $\mathrm{Cu}$ fungicides are shown in Table 1.

\section{Design of grapevines sampling}

In each vineyard, two sets of plants were delimited. For the evaluations performed during the 2009/2010 cycle, three blocks consisting of three plots composed of six plants were delimited: one plot for each stage assessed. For both years, the two most representative grapevines in each plot were used for the investigation. This design was necessary to exclude grapevines exhibiting different sizes and vegetative vigor and to decrease variability of the samples. In the 2010/2011 year, the samplings were always performed on the same plants, and three branches were removed at each stage assessed (Fig. 1).

Soil sampling and analysis

The soil sampling was performed in July 2009 and was restricted to the area used in the study (approximately $1,000 \mathrm{~m}^{2}$ per vineyard). From the three rows of grapevines reserved for the experiment, three soil samples were collected from the $0.00-0.20 \mathrm{~m}$ soil layer. Each sample was composed of nine subsamples, three at each of the following positions: the row, the projection of the canopy of the plants and the middle of the between-row area. Soil samples were also collected in an area of natural field (NF) near the vineyards, which was used as background in the study. The NF was representative of the original vegetation of the soils of this region and was composed primarily of grasses of the genus Paspalum and legumes of the genus Desmodium and Vicia. This vegetation is typical of Pampa Biome and is used as natural pasture; however, this area also exhibits good potential for vineyard cultivation. The samples collected in the vineyards and the NF were air-dried and sieved through a 2-mm mesh. The total concentration of $\mathrm{Cu}\left(\mathrm{Cu}_{\mathrm{T}}\right)$ was extracted in accordance with the United States Environmental Protection Agency (USEPA) method

Table 1 Phenological stages of the grapevines, timeline for tissue sampling and amounts of $\mathrm{Cu}$ applied as fungicide per hectare and equivalent per plant in the period between assessments for the 2009/2010 and 2010/2011 cycles

\begin{tabular}{|c|c|c|c|c|c|c|c|}
\hline \multirow{2}{*}{\multicolumn{2}{|c|}{$\begin{array}{l}\text { Phenological stages } \\
\text { Stage and description (Eichhorn and Lorenz 1977) }\end{array}$}} & \multicolumn{6}{|c|}{ Copper applied } \\
\hline & & \multicolumn{2}{|c|}{ Vineyard 1} & \multicolumn{2}{|c|}{ Vineyard 2} & \multicolumn{2}{|c|}{ Vineyard 3} \\
\hline \multicolumn{2}{|l|}{$2009 / 2010$} & $\mathrm{~g} \mathrm{ha}^{-1}$ & mg plant ${ }^{-1}$ & $\mathrm{~g} \mathrm{ha}^{-1}$ & mg plant ${ }^{-1}$ & $\mathrm{~g} \mathrm{ha}^{-1}$ & mg plant ${ }^{-1}$ \\
\hline EL09 & Two to three leaves & - & - & - & - & - & - \\
\hline EL19 & Beginning of flowering & - & - & - & - & - & - \\
\hline EL31 & Berries pea-sized & - & - & 1250 & 495 & 1250 & 875 \\
\hline Total & & - & - & 1250 & 495 & 1250 & 875 \\
\hline \multicolumn{8}{|l|}{$2010 / 2011$} \\
\hline EL17 & Twelve leaves & - & - & - & - & - & - \\
\hline EL31 & Berries pea-sized $^{\mathrm{a}}$ & 1190 & 428 & 1122 & 444 & 1122 & 785 \\
\hline EL33 & Berry touch & 1370 & 493 & - & - & 1123 & 786 \\
\hline EL37 & Berries not quite ripe $\mathrm{a}^{\mathrm{a}}$ & - & - & - & - & - & - \\
\hline \multicolumn{2}{|l|}{ Total } & 2560 & 921 & 1122 & 444 & 2245 & 1571 \\
\hline
\end{tabular}

\footnotetext{
${ }^{\text {a }}$ Phenological stages when leaf blades were collected for biochemical analysis
} 

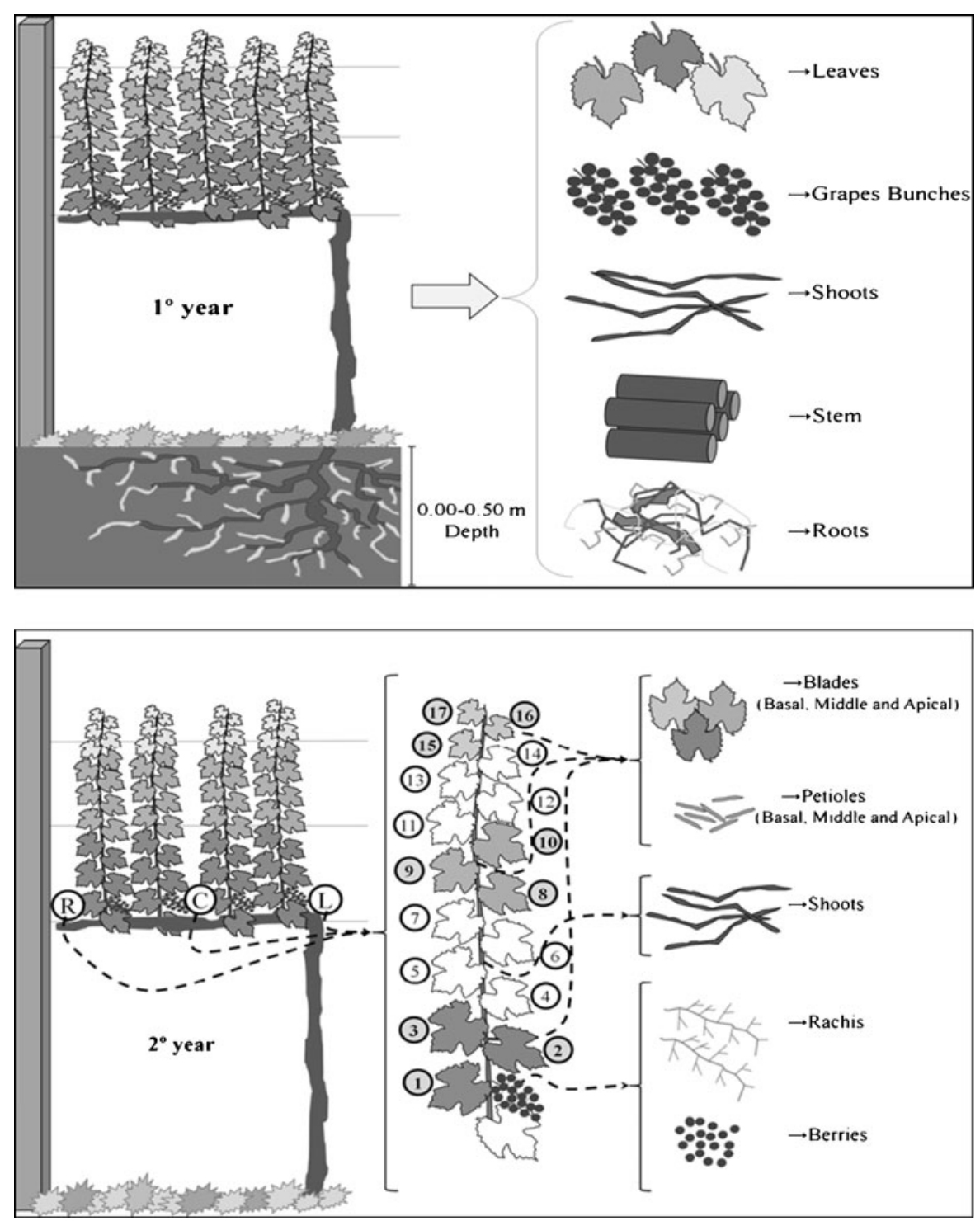

Fig. 1 Figures illustrating the organs and parts of grapevines evaluated at various phenological stages during the 2009/ 2010 cycle (1st year) and the 2010/2011 cycle (2nd year). In the figure representing the 2010/2011 cycle, the letters " $L$, C and $\mathrm{R}$ " indicate the left, central and right positions, respectively, of

3050B (USEPA 1996) by oxidation and acidic attack using $\mathrm{HNO}_{3}, \mathrm{H}_{2} \mathrm{O}_{2}$ and $\mathrm{HCl}$, concentrated under heating. The available concentrations of $\mathrm{Cu}\left(\mathrm{Cu}_{\mathrm{A}}\right)$, iron $\left(\mathrm{Fe}_{\mathrm{A}}\right)$, manganese $\left(\mathrm{Mn}_{\mathrm{A}}\right)$ and zinc $\left(\mathrm{Zn}_{\mathrm{A}}\right)$ were extracted using EDTA (Chaignon et al. 2009). The exchangeable concentrations of calcium $\left(\mathrm{Ca}_{\mathrm{E}}\right)$ and magnesium $\left(\mathrm{Mg}_{\mathrm{E}}\right)$ were extracted using $\mathrm{KCl}$ $\left(1 \mathrm{~mol} \mathrm{~L}^{-1}\right)$. The determination of the concentrations of $\mathrm{Cu}, \mathrm{Fe}, \mathrm{Mn}, \mathrm{Zn}, \mathrm{Ca}$ and $\mathrm{Mg}$ in the extracts was the plants from which the branches were collected at each collection. For these branches, three groups of leaves were sampled. The samples were defined in accordance with their position: basal (numbers 1, 2 and 3); middle (numbers 8, 9 and 10); and apical (numbers 15, 16 and 17)

performed in an atomic absorption spectrophotometer (AAS). The concentrations of available phosphorus $\left(\mathrm{P}_{\mathrm{A}}\right)$ and exchangeable potassium $\left(\mathrm{K}_{\mathrm{E}}\right)$ were extracted using the Mehlich 1 solution $\left(\mathrm{HCl} 0.05 \mathrm{~mol} \mathrm{~L}^{-1}+\right.$ $\mathrm{H}_{2} \mathrm{SO}_{4} 0.0125 \mathrm{~mol} \mathrm{~L}^{-1}$ ), the $\mathrm{P}$ was measured using a spectrophotometer, and the $\mathrm{K}$ was measured using a flame photometer. The $\mathrm{pH}\left(\mathrm{H}_{2} \mathrm{O}\right)$ was determined in a soil:water suspension $(1: 1, \mathrm{~m} / \mathrm{v})$. The effective cation exchange capacity $\left(\mathrm{CEC}_{\mathrm{eff}}\right)$ was calculated using the 
sum of $\mathrm{Ca}_{\mathrm{E}}, \mathrm{Mg}_{\mathrm{E}}$ and $\mathrm{K}_{\mathrm{E}}$ (Tedesco et al. 1995; CQFS$\mathrm{RS} / \mathrm{SC}$ 2004). The concentration of organic matter $(\mathrm{OM})$ in the soil was determined in accordance with the Walkley-Black method, and the particle size was analyzed using the pipette method (Embrapa 1997). The soils were classified as Ultisol (SSS 2010).

Sampling of grapevines and chemical and biochemical analyses

The evaluations were performed on the 2009/2010 and 2010/2011 production cycles. In the first cycle, the $\mathrm{Cu}$ concentration and $\mathrm{Cu}$ content in the various grapevine parts were analyzed. In the second cycle, the $\mathrm{Cu}$ concentration and the physiological responses in the annual aerial organs of the grapevine were investigated in detail. In the 2009/2010 cycle, the grapevines were cut, and each organ was analyzed separately, as shown in Fig. 1. At each stage (Table 1), the amount of fresh matter for each organ was determined, and a subsample was removed to determine the dry matter (DM) and the concentration of $\mathrm{Cu}$. The root system was sampled by opening the trenches to a depth of $0.50 \mathrm{~m}$, a length of 1.50-1.75 m, and a width of $0.75-1.00 \mathrm{~m}$ (according to the planting spacing) to include an area equivalent to one quarter of the area of one plant. Using a 4-mm mesh sieve, the grapevine roots were separated from the soil. Following the division of the roots into subsamples composed of fresh mass derived from the fine $(\leq 1 \mathrm{~mm})$, medium $(1<$ and $\leq 5 \mathrm{~mm})$ and coarse $(<5 \mathrm{~mm})$ portions of the roots, the subsamples were immersed for $8-10 \mathrm{~s}$ in a solution of $\mathrm{HCl}$ $\left(0.5 \mathrm{~mol} \mathrm{~L}^{-1}\right)$ for soil disaggregation, washed in running water, immersed in EDTA $\left(0.02 \mathrm{~mol} \mathrm{~L}^{-1}\right)$ for $1 \mathrm{~min}$ and washed with distilled water three times. Next, the root samples were dried at $60^{\circ} \mathrm{C}$ for $72 \mathrm{~h}$, weighed to determine the dry matter (DW) and milled for analysis. The stem subsamples were composed of five segments measuring 10-12 cm in length, the epidermis was removed manually using a utility knife, and the samples were washed three times in distilled water. The subsamples from the leaves and shoots were also washed three times with distilled water.

In the 2010/2011 cycle, only the annual branches were evaluated. At four phenological stages (Table 1), three branches were removed from each plant and were divided into the parts shown in Fig. 1. The leaves corresponding to the basal, middle and apical positions (Fig. 1) were collected only when fully expanded. The samples were washed three times with distilled water. The grapevines samples that were collected in the two harvests were dried at $60{ }^{\circ} \mathrm{C}$ to a constant weight and ground for analysis.

Samples from the leaf blades were removed for biochemical analyses at the phenological stages EL31 and EL37 of the 2010/2011 cycle (Table 1). After three washes with distilled water, the blades were dried using absorbent paper and were fractionated into halflongitudinal sections, one of which was used for the biochemical analyses and was immediately frozen in liquid $\mathrm{N}_{2}$ and stored in a freezer. The other half of each blade was oven dried at $60{ }^{\circ} \mathrm{C}$ and used to determine the total concentration of nutrients.

\section{Chemical analyses of plant tissues}

To determine the total concentration of $\mathrm{Cu}$ in all the samples and the concentrations of $\mathrm{P}, \mathrm{K}, \mathrm{Ca}$ and $\mathrm{Mg}$ in the leaf blade samples, biochemical analyses were performed after dry digestion of the tissues in a muffle furnace. The samples were calcined at $500-550{ }^{\circ} \mathrm{C}$ for $3 \mathrm{~h}$, and the ashes were diluted in $\mathrm{HNO}_{3}\left(1 \mathrm{~mol} \mathrm{~L}^{-1}\right)$. The total $\mathrm{Cu}, \mathrm{Ca}$ and $\mathrm{Mg}$ concentrations were determined using an AAS, the $\mathrm{K}$ concentration was determined using a flame photometer, and the $\mathrm{P}$ concentration was determined using a spectrophotometer (Embrapa 1997). The concentrations of $\mathrm{N}$ were determined using the semimicro Kjeldahl method (Tedesco et al. 1995).

\section{Biochemical analyses of leaf blades}

The biochemical analyses were performed after maceration of the leaf blades in a mortar using liquid $\mathrm{N}_{2}$. The concentration of hydrogen peroxide $\left(\mathrm{H}_{2} \mathrm{O}_{2}\right)$ was determined by spectrophotometry at $390 \mathrm{~nm}$ and was calculated based on the standard calibration curve, in accordance with Loreto and Velikova (2001). The level of lipid peroxidation was estimated using the TBARS assay, which measures the concentration of malondialdehyde (MDA) using a spectrophotometer at $532 \mathrm{~nm}$ (ElMoshaty et al. 1993). The effect of turbidity in the samples was reduced by subtracting the absorbances at $532 \mathrm{~nm}$ from those obtained at $600 \mathrm{~nm}$. The activity of superoxide dismutase (SOD) was determined by measuring the formation of adrenochrome from epinephrine in alkaline medium using a spectrophotometer at $480 \mathrm{~nm}$ for $4 \mathrm{~min}$ (Misra and Fridovich 1972). A single unit of SOD activity was defined as the amount of enzyme required to inhibit $50 \%$ of the epinephrine oxidation. 
The catalase activity (CAT) was determined using a spectrophotometer at $240 \mathrm{~nm}$ by monitoring the disappearance of the $\mathrm{H}_{2} \mathrm{O}_{2}$ added to the reaction mixture (Aebi 1984). The activity of ascorbate peroxidase (APX) was determined by the ascorbate-dependent oxidation of $\mathrm{H}_{2} \mathrm{O}_{2}$, which was measured by the decrease in absorbance at $290 \mathrm{~nm}$ (Zhu et al. 2004).

\section{Statistical analyses}

The data are presented as the average plus standard deviations. The ANOVA significance test was used to identify significant differences between the variables. When significant differences were detected, the Tukey test was used at $\mathrm{P}<0.05$ for comparison of the averages. A Pearson's linear correlation was established between $\mathrm{DM}, \mathrm{Cu}_{\mathrm{T}}$ and $\mathrm{Cu}_{\mathrm{A}}$ in the soil and the concentration and content of $\mathrm{Cu}$ in the plant tissues.

\section{Results}

Concentration of $\mathrm{Cu}$ and characteristics of the soils

The soils of the vineyards exhibited similar characteristics and increasing $\mathrm{Cu}$ concentrations (Table 2). The soils demonstrated a $\mathrm{pH}\left(\mathrm{H}_{2} \mathrm{O}\right)$ of between 5.5 and 6.0, a sandy texture and a small amount of OM. In the VN2 and VN3 soils, a $\mathrm{Cu}_{\mathrm{T}}$ concentration of 20.5 and $62.4 \mathrm{mg} \mathrm{kg}^{-1}$, respectively, was observed, which was equivalent to 6.4 and 19.5 times the concentration found in the natural field soil (background), respectively. Approximately $80 \%$ of the $\mathrm{Cu}_{\mathrm{T}}$ in the VN2 and VN3 soils was $\mathrm{Cu}_{\mathrm{A}}$ and was potentially available to the plants. The $\mathrm{P}_{\mathrm{A}}$ concentration was interpreted as "High" ( $\left.>21.0 \mathrm{mg} \mathrm{kg}^{-1}\right)$ for VN1 and VN2 and "Very High" ( $>42.0 \mathrm{mg} \mathrm{kg}^{-1}$ ) for VN3 (Table 2) (CQFS-RS/SC 2004). The soils from the vineyards exhibited similar $\mathrm{CEC}_{\text {eff }}$ and concentrations of $\mathrm{K}_{\mathrm{E}}, \mathrm{Ca}_{\mathrm{E}}, \mathrm{Mg}_{\mathrm{E}}, \mathrm{Fe}_{\mathrm{A}}, \mathrm{Zn}_{\mathrm{A}}$ and $\mathrm{Mn}_{\mathrm{A}}$, which were all at sufficient or high concentrations for plants (CQFS$\mathrm{RS} / \mathrm{SC}$ 2004). A small increase in the concentration of $\mathrm{Zn}_{\mathrm{A}}$ was observed in the VN3 soil (Table 2).

Concentration, content and partitioning of $\mathrm{Cu}$ in grapevine (2009-2010 cycle)

The increased concentrations of $\mathrm{Cu}_{\mathrm{T}}$ and $\mathrm{Cu}_{\mathrm{A}}$ in the soils from the vineyards did not increase the concentration of $\mathrm{Cu}$ in the roots, stems, shoots and bunches but were correlated with increased $\mathrm{Cu}$ concentrations in the leaves. The $\mathrm{Cu}$ concentrations in the roots, collected only at stages EL09 and EL19, were equal for the different vineyards and stages evaluated (Fig. 2). The $\mathrm{Cu}$ concentrations in the stems in VN3 were lower than in VN1 and VN2. However, a small change was observed in the three stages evaluated. An average of 5.6, 5.1 and $3.0 \mathrm{mg} \mathrm{kg}^{-1}$ was observed in the stems from $\mathrm{VN} 1, \mathrm{VN} 2$ and $\mathrm{VN} 3$, respectively (Fig. 2). The application of $\mathrm{Cu}$-based fungicide in VN2 and VN3 between stages EL19 and EL31, did not affect the $\mathrm{Cu}$ concentration in the stem. The $\mathrm{Cu}$ concentration in the shoots decreased in the first two stages assessed (Fig. 2), and the values were, on average, $11.7 \mathrm{mg} \mathrm{kg}^{-1}$ in the $\mathrm{VN} 1,7.3 \mathrm{mg} \mathrm{kg}^{-1}$ in VN2 and $8.0 \mathrm{mg} \mathrm{kg}^{-1}$ in VN3. In contrast, at stage EL31 in VN2 and $\mathrm{VN} 3$, an increase in the $\mathrm{Cu}$ concentration was observed, most likely because of residual fungicide from the application. In the bunches, the $\mathrm{Cu}$ values at stage EL19 were similar for the grapevines from the three vineyards (approximately $7.0 \mathrm{mg} \mathrm{kg}^{-1} \mathrm{DW}$ ). However, after the application of the $\mathrm{Cu}$-based fungicides, the $\mathrm{Cu}$ concentration increased several-fold and reached values above $50 \mathrm{mg} \mathrm{kg}^{-1}$ in $\mathrm{VN} 2$ and $90 \mathrm{mg} \mathrm{kg}^{-1}$ in VN3 (Fig. 2). The Cu concentration in the leaves from the three vineyards at stage EL09 was not altered by the $\mathrm{Cu}$ in the soil. However, at stage EL19, higher concentrations of $\mathrm{Cu}$ were observed in the leaves from $\mathrm{VN} 3$, which coincided with the higher concentrations of $\mathrm{Cu}_{\mathrm{T}}$ and $\mathrm{Cu}_{\mathrm{A}}$ in the soil. At this stage, the concentration values for $\mathrm{Cu}$ in the leaves were, on average, $7.1,8.0$ and $10.5 \mathrm{mg} \mathrm{kg}^{-1}$ in VN1, VN2 and $\mathrm{VN} 3$, respectively. The higher $\mathrm{Cu}$ concentration in the leaves observed in VN3, although numerically small, represented an increase of $47 \%$ and $31 \%$ compared to VN1 and VN2, respectively. After the application of the $\mathrm{Cu}$-based fungicide, $\mathrm{Cu}$ concentrations above $140 \mathrm{mg} \mathrm{kg}^{-1}$ were observed in the leaves from VN2 and VN3. However, in VN1, without the fungicide application, the $\mathrm{Cu}$ concentration was $19.3 \mathrm{mg} \mathrm{kg}^{-1}$.

In general, the $\mathrm{Cu}$ content in the roots from VN3 was higher than in VN1 and VN2, which exhibited similar values (Fig. 2). The $\mathrm{Cu}$ content in the shoots at stages EL09 and EL19 was similar for the three vineyards. At stage EL19, the $\mathrm{Cu}$ content of the bunches was slightly higher in VN2 compared with $\mathrm{VN} 1$ and VN3. Moreover, the $\mathrm{Cu}$ content in the leaves was consistently higher in VN3 for the three stages assessed. However, notably, at stage EL31, the $\mathrm{Cu}$ 
Table 2 Chemical and physical attributes of the $0.00-0.20 \mathrm{~m}$ layer of the soil collected in the three vineyards evaluated in a natural field area

\begin{tabular}{|c|c|c|c|c|}
\hline Characteristics & Natural field (background) & Vineyard 1 & Vineyard 2 & Vineyard 3 \\
\hline $\mathrm{Cu}_{\mathrm{T}}, \mathrm{mg} \mathrm{kg}^{-1}$ & $3.2 \pm 0.1^{\mathrm{c}}$ & $4.7 \pm 0.7^{\mathrm{c}}$ & $20.5 \pm 2.4^{\mathrm{b}}$ & $62.4 \pm 6.7^{\mathrm{a}}$ \\
\hline $\mathrm{Cu}_{\mathrm{A}}, \mathrm{mg} \mathrm{kg}^{-1}$ & $1.1 \pm 0.1^{\mathrm{c}}$ & $2.2 \pm 0.3^{\mathrm{c}}$ & $17.2 \pm 2.8^{\mathrm{b}}$ & $49.6 \pm 6.8^{\mathrm{a}}$ \\
\hline $\mathrm{P}_{\mathrm{A}}, \mathrm{mg} \mathrm{kg}^{-1}$ & $5.9 \pm 1.0^{\mathrm{c}}$ & $28.4 \pm 2.5^{b}$ & $30.0 \pm 2.2^{\mathrm{b}}$ & $48.2 \pm 4.3^{\mathrm{a}}$ \\
\hline $\mathrm{K}_{\mathrm{E}}, \mathrm{mg} \mathrm{kg}^{-1}$ & $131.0 \pm 10.2^{\mathrm{ns}}$ & $148.0 \pm 15.5$ & $149.0 \pm 8.2$ & $165.0 \pm 18.7$ \\
\hline $\mathrm{Ca}_{\mathrm{E}}, \mathrm{cmol}_{\mathrm{c}} \mathrm{kg}^{-1}$ & $0.4 \pm 0.1^{\mathrm{b}}$ & $1.1 \pm 0.2^{\mathrm{a}}$ & $0.9 \pm 0.1^{\mathrm{a}}$ & $0.8 \pm 0.1^{\mathrm{ab}}$ \\
\hline $\mathrm{Mg}_{\mathrm{E}}, \mathrm{cmol}_{\mathrm{c}} \mathrm{kg}^{-1}$ & $0.2 \pm 0.1^{\mathrm{c}}$ & $0.6 \pm 0.1^{\mathrm{a}}$ & $0.4 \pm 0.1^{\mathrm{b}}$ & $0.5 \pm 0.1^{\mathrm{b}}$ \\
\hline $\mathrm{Zn}_{\mathrm{A}}, \mathrm{mg} \mathrm{kg}^{-1}$ & $3.0 \pm 0.1^{\mathrm{bc}}$ & $1.7 \pm 0.4^{\mathrm{c}}$ & $4.8 \pm 0.4^{\mathrm{b}}$ & $10.1 \pm 1.6^{\mathrm{a}}$ \\
\hline $\mathrm{Fe}_{\mathrm{A}}, \mathrm{mg} \mathrm{kg}^{-1}$ & $32.8 \pm 1.9^{\mathrm{ns}}$ & $30.6 \pm 4.2$ & $26.0 \pm 0.3$ & $29.1 \pm 2.5$ \\
\hline $\mathrm{Mn}_{\mathrm{A}}, \mathrm{mg} \mathrm{kg}^{-1}$ & $49.0 \pm 2.8^{\mathrm{ns}}$ & $40.4 \pm 1.6$ & $50.5 \pm 7.5$ & $54.1 \pm 2.2$ \\
\hline $\mathrm{pH}-\mathrm{H}_{2} \mathrm{O}$ & $5.1 \pm 0.1^{\mathrm{c}}$ & $5.5 \pm 0.2^{\mathrm{b}}$ & $6.0 \pm 0.1^{\mathrm{a}}$ & $5.7 \pm 0.1^{\mathrm{ab}}$ \\
\hline $\mathrm{CEC}_{\mathrm{Eff}}, \mathrm{cmol}_{\mathrm{c}} \mathrm{kg}^{-1}$ & $1.4 \pm 0.1^{\mathrm{b}}$ & $2.3 \pm 0.4^{\mathrm{a}}$ & $1.9 \pm 0.1^{\mathrm{ab}}$ & $1.9 \pm 0.1^{\mathrm{ab}}$ \\
\hline $\mathrm{OM}, \mathrm{g} \mathrm{kg}^{-1}$ & $6.9 \pm 0.2^{\mathrm{b}}$ & $8.8 \pm 0.4^{\mathrm{a}}$ & $7.0 \pm 0.3^{\mathrm{b}}$ & $8.2 \pm 0.3^{\mathrm{a}}$ \\
\hline Clay fraction, $\mathrm{g} \mathrm{kg}^{-1}$ & $58.2 \pm 5.2^{\mathrm{a}}$ & $63.4 \pm 4.5^{\mathrm{a}}$ & $48.2 \pm 0.2^{\mathrm{b}}$ & $43.3 \pm 0.1^{\mathrm{b}}$ \\
\hline
\end{tabular}

Averages followed by the same letter in rows do not differ according to the Tukey test at $P<0.05$. The data represent the mean \pm S.D. of three replicates

$T$ total; $A$ available; $E$ exchangeable; Eff effective; $n s$ not significant

content in leaves, shoots and bunches from the VN2 and VN3 plants was considerably higher, likely because of the application of the $\mathrm{Cu}$-based fungicides (Fig. 2).

At stage EL19, when no fungicide was applied, the $\mathrm{Cu}$ contents in the bunches from VN1, VN2 and VN3 were $14.8,14.2$ and $28.9 \mathrm{mg}$ plant $^{-1}$, respectively. The roots and stems exhibited the most $\mathrm{Cu}$ accumulation. Together, these organs exhibited a cumulative total per plant of $91.0 \%$ in VN1, $98.7 \%$ in VN2 and $99.2 \%$ in VN3. Individually, the roots and stems represented 57.8 and $33.8 \%$ in $\mathrm{VN} 1,86.2$ and $12.5 \%$ in $\mathrm{VN} 2$, and 75.1 and $24.1 \%$ in VN3, respectively. The copper content in the leaves and shoots from VN1 equaled $3.8 \%$ of the total accumulation for the plant and less than $1 \%$ for VN2 and VN3. The shoots represented $0.6 \%$ of the cumulative total in VN1, $0.1 \%$ in VN2 and only $0.03 \%$ in VN3.

The correlation analysis was performed at the EL09 and EL19 stages, when no application of Cu-based fungicides was performed. $\mathrm{The}_{\mathrm{Cu}}$ and $\mathrm{Cu}_{\mathrm{A}}$ contents in the soil either were weakly correlated with the concentrations of $\mathrm{Cu}$ in the roots, stems, shoots and bunches or did not explain these concentrations (Table 3). The concentrations of $\mathrm{Cu}$ in the soils was weakly affected by $\mathrm{Cu}$ concentration in the leaves at stage EL09 but correlated positively with the concentrations observed at stage EL19. The amount of $\mathrm{Cu}$ accumulated in the roots, stems, bunches and leaves correlated positively with the amount of DM, with the exception of the shoots at the EL09 stage (Table 3, Fig. 2). The cumulative amount also correlated with $\mathrm{Cu}_{\mathrm{T}}$ and $\mathrm{Cu}_{\mathrm{A}}$ in the soil; however, the DM was responsible for most of the variance, whereas the total $\mathrm{Cu}$ concentration values were altered slightly by the concentrations in the soil.

$\mathrm{Cu}$ concentration in annual branches $(2010 / 2011$ cycles)

In the second evaluation cycle, the data obtained at phenological stage EL17 corroborated the data obtained at stage EL19 of the 2009/2010 cycle (Fig. 3). The data demonstrated that the $\mathrm{Cu}$ concentrations in the leaf blades and shoots were higher in VN3, which demonstrated the highest $\mathrm{Cu}$ accumulation in the soil. At stage EL17, the $\mathrm{Cu}$ concentrations were 9.4 and $7.9 \mathrm{mg} \mathrm{kg}^{-1}$ in VN1, 9.7 and $9.4 \mathrm{mg} \mathrm{kg}^{-1}$ in $\mathrm{VN} 2$, and 12.6 and $26.7 \mathrm{mg} \mathrm{kg}^{-1}$ in VN3 for the shoots and basal leaf blades (BB), respectively (Fig. 3). These concentrations represented an average increase of $31 \%$ for the shoots and a 2-to 3-fold increase for the $\mathrm{BB}$ in $\mathrm{VN} 3$ compared to $\mathrm{VN} 1$ and $\mathrm{VN} 2$. In these organs, a positive correlation was observed between 

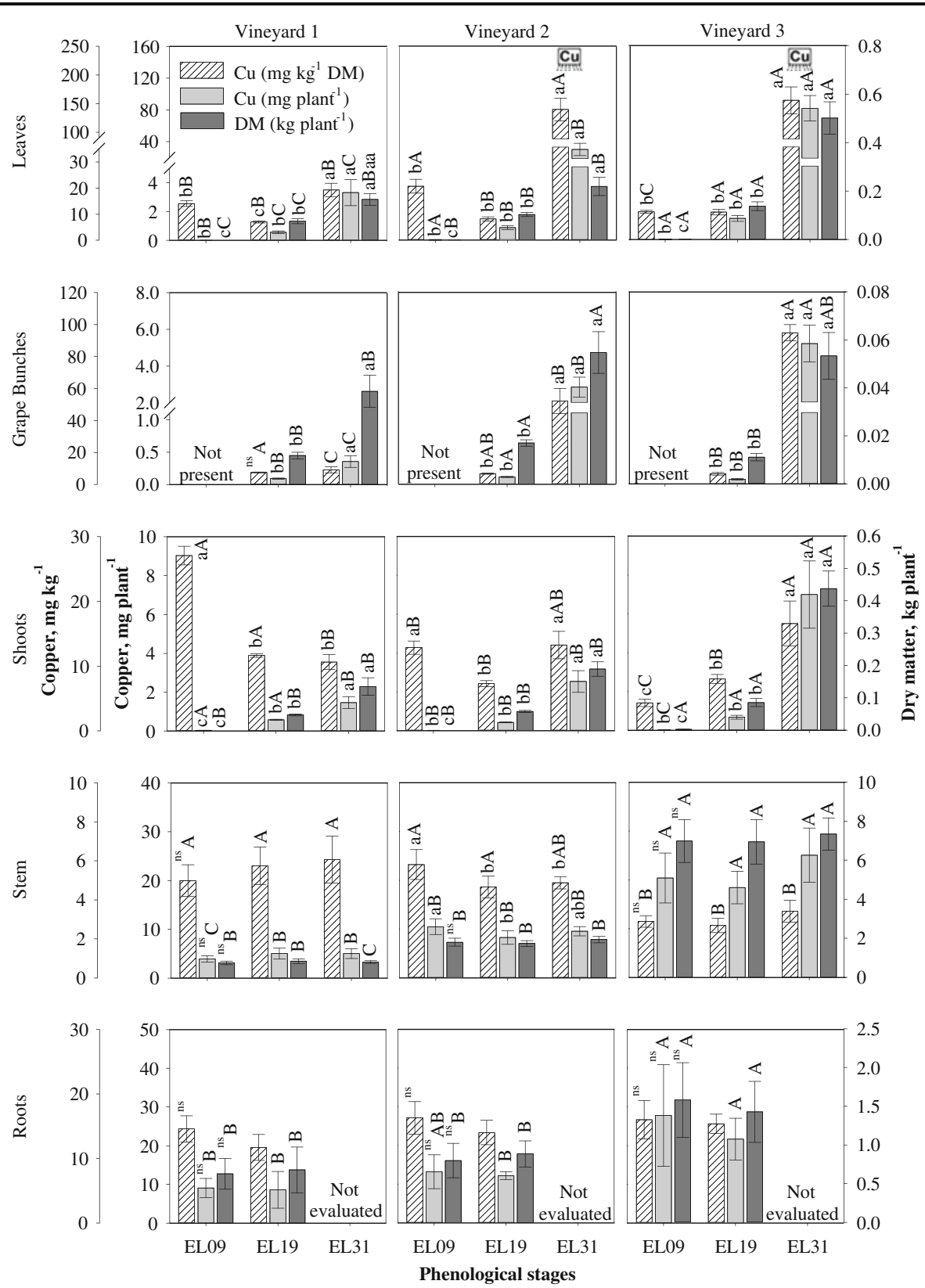

Fig. 2 Dry matter production, copper concentration and content in perennial and annual organs of grapevines grown on soils containing increasing levels of $\mathrm{Cu}$ during the 2009/2010 cycle. The same letters on the columns, lowercase for the phenological stages of a single vineyard and uppercase for vineyards and a

the concentrations of $\mathrm{Cu}_{\mathrm{T}}$ and $\mathrm{Cu}_{\mathrm{A}}$ in the soil and the $\mathrm{Cu}$ concentration in the tissues (Table 3 ).

The residual $\mathrm{Cu}$-based fungicides affected the copper concentrations in the tissues at stages EL31, EL33 and EL37. The Cu-based fungicide applications were performed between stages EL17 and EL37, and an single phenological stage, indicate no differences according to the Tukey test at $P<0.05$. $n s$ not significant. $\mathrm{Cu}_{\mathrm{m}}$ Application of $\mathrm{Cu}$-based fungicide in the period between the phenological stage indicated and the previous stage (Table 1)

increase in the $\mathrm{Cu}$ concentrations in mainly the leaf blades, petioles and rachis was observed (Fig. 3). In addition, the fungicides slightly affected the $\mathrm{Cu}$ concentrations in the shoots and berries. The $\mathrm{Cu}$ concentration in the leaf blades was high, often above $100 \mathrm{mg} \mathrm{kg}^{-1}$, and in some cases, it was more than 
Table 3 Correlation between $\mathrm{Cu}$ concentrations and content in different organs of grapevines and the dry matter, total concentration and available $\mathrm{Cu}$ in the soil. The data pertain to stages
EL09 and EL19 of the 2009/2010 cycle and EL17 of the 2010/ 2011 cycle, when no $\mathrm{Cu}$-based fungicides were applied

\begin{tabular}{|c|c|c|c|c|}
\hline Variable & $\mathrm{n}$ & CuTSoil & CuASoil & Dry matter \\
\hline $\mathrm{Cu}$ in grapevine tissues & & \multicolumn{3}{|c|}{ EL09, two to three leaves $(2009 / 2010)$} \\
\hline Leaves $\mathrm{CuC}$ & 18 & $-0.32 *$ & $-0,28 *$ & $-0.26^{*}$ \\
\hline Leaves CuT & 18 & $0.25 *$ & $0.29^{*}$ & $0.34^{*}$ \\
\hline Grape bunches $\mathrm{CuC}$ & & - & - & - \\
\hline Grape bunches $\mathrm{CuT}$ & & - & - & - \\
\hline Shoots $\mathrm{CuC}$ & 18 & $-0.83^{* *}$ & $-0.86^{* *}$ & $-0.64 * *$ \\
\hline Shoots CuT & 18 & $-0.77 * *$ & $-0.80 * *$ & $-0.50 * *$ \\
\hline Stem $\mathrm{CuC}$ & 18 & $-0.58 * *$ & $-0.55^{* *}$ & $-0.59 * *$ \\
\hline Stem CuT & 18 & $0.80 * *$ & $0.81 * *$ & $0.89^{* *}$ \\
\hline Roots $\mathrm{CuC}$ & 12 & ns & ns & ns \\
\hline \multirow[t]{2}{*}{ Roots $\mathrm{CuT}$} & 12 & $0.50^{*}$ & $0.50 *$ & $0.95 * *$ \\
\hline & & \multicolumn{3}{|c|}{ EL19, beginning of flowering $(2009 / 2010)$} \\
\hline Leaves $\mathrm{CuC}$ & 18 & $0.77 * *$ & $0.77^{* *}$ & $0.54 * *$ \\
\hline Leaves CuT & 18 & $0.86 * *$ & $0.86^{* *}$ & $0.89^{* *}$ \\
\hline Grape bunches $\mathrm{CuC}$ & 18 & $-0.25^{*}$ & $-0.27 *$ & ns \\
\hline Grape bunches $\mathrm{CuT}$ & 18 & $-0.32 *$ & $-0.29 *$ & $0.83^{* *}$ \\
\hline Shoots $\mathrm{CuC}$ & 18 & $-0.33^{*}$ & $-0.38^{* *}$ & $-0.33^{*}$ \\
\hline Shoots CuT & 18 & $0.28 *$ & $0.24^{*}$ & $0.42 * *$ \\
\hline Stem $\mathrm{CuC}$ & 18 & $-0.77 * *$ & $-0.78 * *$ & $-0.72 * *$ \\
\hline Stem $\mathrm{CuT}$ & 18 & $0.87 * *$ & $0.87^{* *}$ & $0.90 * *$ \\
\hline Roots $\mathrm{CuC}$ & 12 & $0.35^{*}$ & $0.36^{*}$ & ns \\
\hline \multirow[t]{2}{*}{ Roots $\mathrm{CuT}$} & 12 & $0.63 * *$ & $0.63^{* *}$ & $0.93 * *$ \\
\hline & & \multicolumn{3}{|c|}{ EL 17, twelve leaves $(2010 / 2011)$} \\
\hline Basal blades $\mathrm{CuC}$ & 24 & $0.70 * *$ & $0.68 * *$ & - \\
\hline Basal petioles $\mathrm{CuC}$ & 24 & ns & ns & - \\
\hline Berries $\mathrm{CuC}$ & - & - & - & - \\
\hline Rachis $\mathrm{CuC}$ & 24 & ns & $\mathrm{ns}$ & - \\
\hline Shoot $\mathrm{CuC}$ & 24 & $0.45^{*}$ & $0.44 *$ & - \\
\hline
\end{tabular}

$C u C \mathrm{Cu}$ concentration; $C u T \mathrm{Cu}$ content; $n s$ not significant

*significant at $P<0.05$

**significant at $P<0.01$

$400 \mathrm{mg} \mathrm{kg}^{-1}$, as observed in the blades at stage EL33 in VN1. The copper concentration in the petioles was not proportional to the concentrations in the leaf blades. In the petioles from the basal, middle and apical leaves at stage EL33, the maximum concentration of $\mathrm{Cu}$ was $80 \mathrm{mg} \mathrm{kg}^{-1}$ in VN1; however, lower values (between 20 and $40 \mathrm{mg} \mathrm{kg}^{-1}$ ) were often observed in the three vineyards (Fig. 3). At stage EL37, the $\mathrm{Cu}$ concentration in the petioles collected from three positions on the branches were, on average, $33.6 \mathrm{mg} \mathrm{kg}^{-1}$ in $\mathrm{VN} 1$; however, the concentrations were $12.1 \mathrm{mg} \mathrm{kg}^{-1}$ in
$\mathrm{VN} 2$ and $16.3 \mathrm{mg} \mathrm{kg}^{-1}$ in VN3. At this stage, the leaf blades from the three vineyards still demonstrated high $\mathrm{Cu}$ concentrations, ranging from 50 to greater than $300 \mathrm{mg} \mathrm{kg}^{-1}$. The $\mathrm{Cu}$ concentration in the rachis was similar to that in the petioles; however, the concentrations were always lower than in the leaf blades. The $\mathrm{Cu}$ concentrations in the shoots of the grapevines from the three vineyards were not affected by the application of the Cu-based fungicides. However, in the final evaluation, the concentration of $\mathrm{Cu}$ in the shoots was $18.6 \mathrm{mg} \mathrm{kg}^{-1}$ in $\mathrm{VN} 1,10.4 \mathrm{mg} \mathrm{kg}^{-1}$ in $\mathrm{VN} 2$, and 

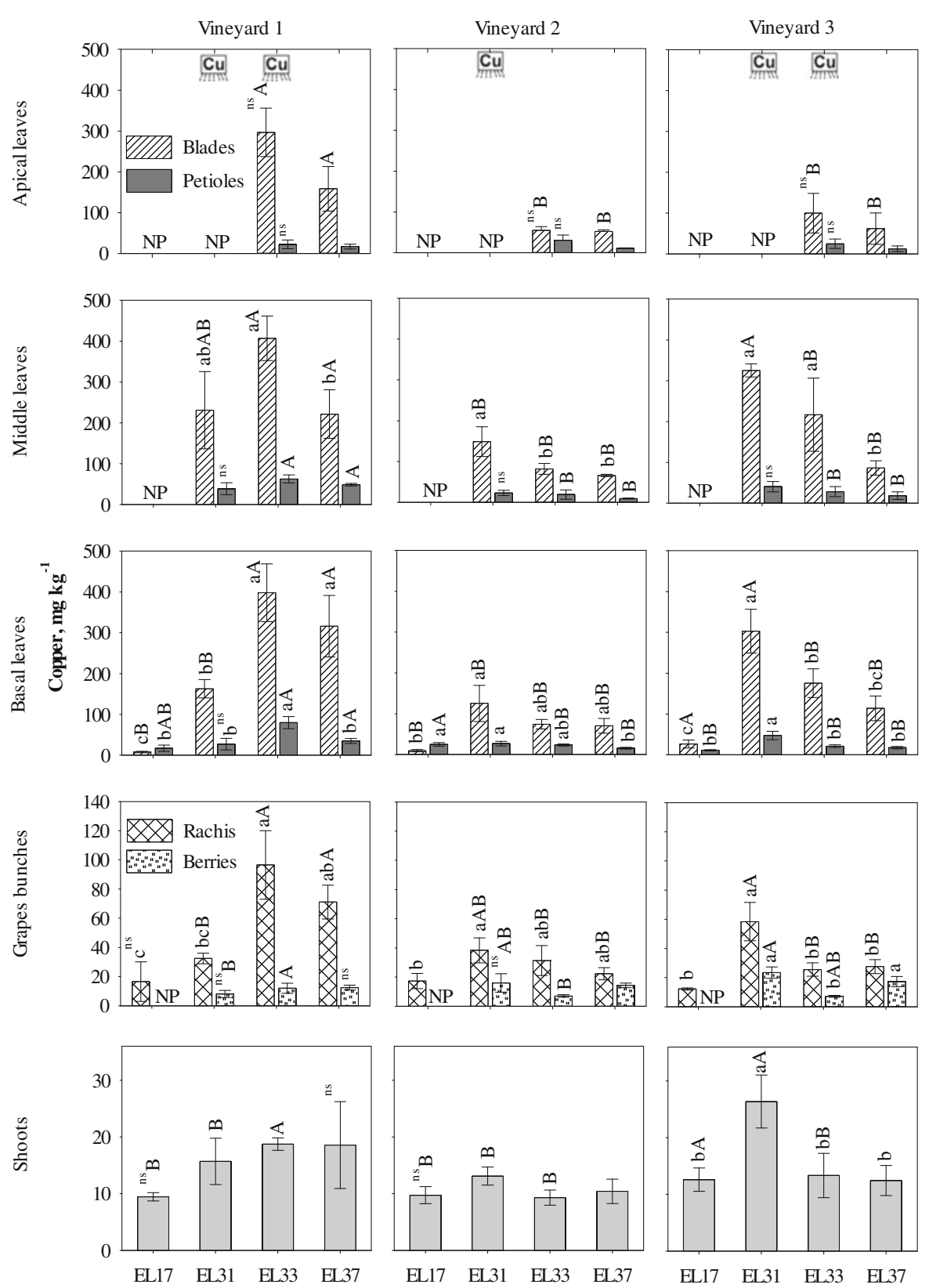

Phenological stages

Fig. 3 Copper concentrations in annual organs of grapevines grown on soils containing increasing levels of $\mathrm{Cu}$ during the $2010 / 2011$ cycle. The same letters on the columns, lowercase letters for phenological stages of a single vineyard and uppercase letters for vineyards and a single phenological stage, indicate no

$12.3 \mathrm{mg} \mathrm{kg}^{-1}$ in VN3 (Fig. 3). These data, particularly the data observed in VN2 and VN3, were very close to those observed at stage EL17, before the application of the $\mathrm{Cu}$-based fungicides. In contrast, the $\mathrm{Cu}$ difference according to the Tukey test at $P<0.05$. ns not significant, $N P$ not present. $\mathrm{Cu}_{\mathrm{m}}$ Application of $\mathrm{Cu}$-based fungicide in the period between the phenological stage indicated and the previous stage (Table 1)

concentration in the berries was affected slightly by the concentrations in the soil and the application of the $\mathrm{Cu}$-based fungicides. In general, the $\mathrm{Cu}$ concentration in the berries from the three vineyards ranged between 8 
and $20 \mathrm{mg} \mathrm{kg}^{-1}$. At stage EL31 (when the berries were not quite ripe), the $\mathrm{Cu}$ concentrations in the berries were $12.4 \mathrm{mg} \mathrm{kg}^{-1}$ in the VN1 grapevines, $3.14 \mathrm{mg} \mathrm{kg}^{-1}$ in the VN2 grapevines and $17.3 \mathrm{mg} \mathrm{kg}^{-1}$ in the VN3 grapevines (Fig. 3).

\section{Concentration of macronutrients in leaf blades}

The concentration of macronutrients in the leaf blades was very similar for the three vineyards (Table 4). Based on the reference concentrations for the full leaves (normal concentration $=16.0-24.0 \mathrm{mg} \mathrm{kg}^{-1}$ for $\mathrm{N}$; $1.2-4.0 \mathrm{mg} \mathrm{kg}^{-1}$ for $\mathrm{P}$; and $8.0-16.0 \mathrm{mg} \mathrm{kg}^{-1}$ for $\mathrm{K}$ ), the concentrations of $\mathrm{N}, \mathrm{P}, \mathrm{K}$ were interpreted as normal, and in some cases very high, at both stages that were evaluated (CQFS-RS/SC 2004). The Ca concentrations did not differ between the vineyards. In contrast, the Mg concentration at stage EL37 was slightly higher in VN1 but did not differ from that in VN3. The calcium concentrations between 16.0 and $24.0 \mathrm{mg} \mathrm{kg}^{-1}$ and the $\mathrm{Mg}$ concentrations between 2.0 and $6.0 \mathrm{mg} \mathrm{kg}^{-1}$ (CQFS, RS/SC 2004) were considered normal for full leaves. Between stages EL31 and EL37, the concentration of $\mathrm{N}, \mathrm{P}$ and $\mathrm{K}$ decreased, whereas the concentrations of $\mathrm{Ca}$ and $\mathrm{Mg}$ increased (Table 4).

Biochemical analyses of leaf blades

For the 2010/2011 cycle, the biochemical analyses for oxidative stress were performed at stages EL31 in the basal (BB) and middle (MB) leaf blades and at stage EL37 in the BB, MB, and apical blades (AB). An increased concentration of $\mathrm{H}_{2} \mathrm{O}_{2}$ was observed in the three vineyards at stage EL31 in the BB and at stage EL37 in particular in the MB; however, statistically, the values were identical to the other assessments (Fig. 4). At stage EL31, the lipid peroxidation (MDA) in the BB was lower in VN2 than in VN1 and VN3. At stage EL37, the lipid peroxidation did not change in the three vineyards (Fig. 4). The SOD activity demonstrated significant variation for the vineyards and stages assessed (Fig. 4). The data revealed a higher activity for this enzyme in the leaf blades from VN2 and VN3

middle and apical positions in branches of grapevines grown on soils with increasing $\mathrm{Cu}$ concentration during 2010/2011 cycle

Table 4 Total concentrations of nitrogen, phosphorus, potassium, calcium and magnesium in leaf blades collected at two phenological stages (EL 31 and EL 37) and located at the basal,

\begin{tabular}{|c|c|c|c|c|c|c|c|}
\hline \multirow[t]{2}{*}{ Position } & \multirow[t]{2}{*}{ Nutrient $\mathrm{g} \mathrm{kg}^{-1}$} & \multicolumn{2}{|l|}{ Vineyard 1} & \multicolumn{2}{|l|}{ Vineyard 2} & \multicolumn{2}{|l|}{ Vineyard 3} \\
\hline & & EL 31 & EL 37 & EL 31 & EL 37 & EL 31 & EL 37 \\
\hline \multirow[t]{5}{*}{ Apical blades (AB) } & $\mathrm{N}$ & NP & $24.2 \pm 2.0^{\mathrm{ns}}$ & NP & $23.9 \pm 2.1$ & NP & $21.8 \pm 1.7$ \\
\hline & $\mathrm{P}$ & & $2.6 \pm 0.1^{\mathrm{B}}$ & & $3.1 \pm 0.2^{\mathrm{A}}$ & & $2.3 \pm 0.1^{\mathrm{C}}$ \\
\hline & $\mathrm{K}$ & & $6.9 \pm 1.2^{\mathrm{B}}$ & & $12.9 \pm 1.1^{\mathrm{A}}$ & & $10.2 \pm 1.5^{\mathrm{AB}}$ \\
\hline & $\mathrm{Ca}$ & & $18.3 \pm 0.5^{\mathrm{A}}$ & & $16.5 \pm 0.7^{\mathrm{AB}}$ & & $15.1 \pm 2.4^{\mathrm{B}}$ \\
\hline & $\mathrm{Mg}$ & & $7.7 \pm 0.4^{\mathrm{A}}$ & & $4.9 \pm 0.7^{\mathrm{B}}$ & & $5.1 \pm 0.4^{\mathrm{B}}$ \\
\hline \multirow[t]{5}{*}{ Middle blades (MB) } & $\mathrm{N}$ & $24.4 \pm 1.4^{\mathrm{nsNS}}$ & $21.6 \pm 0.8^{\mathrm{NS}}$ & $24.8 \pm 1.3^{\mathrm{ns}}$ & $23.7 \pm 2.3$ & $21.7 \pm 1.3^{\mathrm{ns}}$ & $21.6 \pm 0.8$ \\
\hline & $\mathrm{P}$ & $3.6 \pm 0.5^{\mathrm{aNS}}$ & $2.5 \pm 0.2^{\mathrm{bB}}$ & $3.9 \pm 0.4^{\mathrm{a}}$ & $3.3 \pm 0.2^{\mathrm{bA}}$ & $3.6 \pm 0.2^{\mathrm{a}}$ & $2.2 \pm 0.1^{\mathrm{bB}}$ \\
\hline & $\mathrm{K}$ & $11.5 \pm 1.2^{\mathrm{aB}}$ & $7.9 \pm 1.4^{\mathrm{bC}}$ & $16.1 \pm 1.6^{\mathrm{nsA}}$ & $14.4 \pm 0.8^{\mathrm{A}}$ & $13.2 \pm 1.5^{\mathrm{nsAB}}$ & $10.9 \pm 0.6^{\mathrm{B}}$ \\
\hline & $\mathrm{Ca}$ & $8.8 \pm 0.6^{\mathrm{bNS}}$ & $17.2 \pm 0.8^{\mathrm{aNS}}$ & $10.1 \pm 1.4^{\mathrm{b}}$ & $17.3 \pm 0.8^{\mathrm{a}}$ & $9.7 \pm 1.4^{\mathrm{b}}$ & $15.9 \pm 1.5^{\mathrm{a}}$ \\
\hline & $\mathrm{Mg}$ & $4.1 \pm 0.5^{\mathrm{bNS}}$ & $6.7 \pm 0.5^{\mathrm{aA}}$ & $3.2 \pm 0.3^{\mathrm{ns}}$ & $4.7 \pm 1.1^{\mathrm{B}}$ & $3.6 \pm 0.5^{\mathrm{b}}$ & $5.0 \pm 0.4^{\mathrm{aAB}}$ \\
\hline \multirow[t]{5}{*}{ Basal blades (BB) } & $\mathrm{N}$ & $23.4 \pm 0.9^{\mathrm{nsNS}}$ & $23.9 \pm 2.8^{\mathrm{A}}$ & $22.6 \pm 1.5^{\mathrm{ns}}$ & $21.4 \pm 0.5^{\mathrm{AB}}$ & $22.2 \pm 0.6^{\mathrm{ns}}$ & $18.5 \pm 3.1^{\mathrm{B}}$ \\
\hline & $\mathrm{P}$ & $3.1 \pm 0.1^{\mathrm{aB}}$ & $2.3 \pm 0.1^{\mathrm{bB}}$ & $3.9 \pm 0.4^{\mathrm{nsAB}}$ & $4.4 \pm 0.4^{\mathrm{A}}$ & $4.0 \pm 0.3^{\mathrm{aA}}$ & $2.8 \pm 0.5^{\mathrm{bB}}$ \\
\hline & $\mathrm{K}$ & $10.9 \pm 1.1^{\mathrm{nsB}}$ & $9.6 \pm 1.2^{\mathrm{B}}$ & $14.4 \pm 0.8^{\mathrm{aA}}$ & $12.9 \pm 1.1^{\mathrm{bAB}}$ & $11.7 \pm 0.6^{\mathrm{nsB}}$ & $11.3 \pm 0.6^{\mathrm{B}}$ \\
\hline & $\mathrm{Ca}$ & $11.9 \pm 1.4^{\mathrm{aB}}$ & $19.8 \pm 3.7^{\mathrm{bNS}}$ & $13.1 \pm 1.2^{\mathrm{bB}}$ & $22.5 \pm 1.3^{\mathrm{a}}$ & $17.6 \pm 3.0^{\mathrm{bA}}$ & $25.3 \pm 2.4^{\mathrm{a}}$ \\
\hline & $\mathrm{Mg}$ & $4.2 \pm 0.2^{\mathrm{bA}}$ & $6.0 \pm 0.6^{\mathrm{aA}}$ & $2.8 \pm 0.2^{\mathrm{aB}}$ & $3.9 \pm 0.2^{\mathrm{bB}}$ & $4.4 \pm 0.6^{\mathrm{bA}}$ & $5.7 \pm 0.4^{\mathrm{aA}}$ \\
\hline
\end{tabular}

The averages followed by the same letter on the same line (lowercase letters for phenological stages for a single vineyard and uppercase letter for vineyards and a single phenological stage) do not differ according to the Tukey test at $P<0.05$

$n s$ not significant; NP not present 
in the MB at stage EL31 and in the BB and AB at stage EL37. In contrast, the SOD activity was lower in VN3 in the BB at stage EL31 and was equal to the activity in VN1 in the MB at stage EL37. The CAT activity at stage EL37 was higher in VN3 in the MB and in VN2 and $\mathrm{VN} 3$ in the $\mathrm{AB}$ compared with $\mathrm{VN} 1$. In the other assessments, the CAT activity demonstrated a slight variation in the different vineyards, with the exception of stage EL31 in the BB, in which the enzyme activity was lower in VN3 compared with VN1 (Fig. 4). The activity of APX was consistently lower in the leaf blades from VN2 and VN3, with the exception of the $\mathrm{BB}$ at stage EL31, in which the VN2 demonstrated the lowest activity (Fig. 4). The copper concentration in the leaf blades, largely derived from the residual fungicide, and the macronutrient concentration did not correlate with the concentration of $\mathrm{H}_{2} \mathrm{O}_{2}$ and MDA or the activity of SOD, CAT and APX (data not shown).

\section{Discussion}

Characteristics of the vineyard soils

The copper accumulation found in the soil in VN2 and VN3 was attributed to the foliar application of $\mathrm{Cu}-$ based fungicides over the years. The total copper in the topsoil $\left(20.5 \mathrm{mg} \mathrm{kg}^{-1}\right.$ in VN2 and $62.4 \mathrm{mg} \mathrm{kg}^{-1}$ in $\mathrm{VN} 3$, Table 2) was considered to be at a median or low level compared to the levels reported in the literature or by government regulatory agencies. Studies performed in many wine regions of the world have reported maximum concentrations of $\mathrm{Cu}$ in vineyard soils ranging from 200 to greater than $600 \mathrm{mg} \mathrm{kg}^{-1}$ (Brun et al. 1998; Arias et al. 2004; Casali et al. 2008). However, according to government regulatory agencies in Brazil, a concentration of $60 \mathrm{mg} \mathrm{Cu} \mathrm{kg}^{-1}$ soil indicates the need for preventative measures, although the maximum concentration suggested is $200 \mathrm{mg} \mathrm{kg}^{-1}$ (CETESB 2005;

Fig. 4 Concentration of $\mathrm{H}_{2} \mathrm{O}_{2}$, level of lipid peroxidation (MDA), and activities of the enzymes SOD, CAT and APX in leaf blades collected at three positions (basal, middle and apical) in the branches and at two vegetative stages (EL31 and EL37) during the 2010/2011 cycle, in three vineyards with increasing levels of $\mathrm{Cu}$ in the soil. The same letters on the columns, lowercase for vineyard and a single phenological stage and uppercase for phenological stages and a single vineyard, indicate no difference according to the Tukey test at $P<0.05$. NP not present, $n s$ not significant
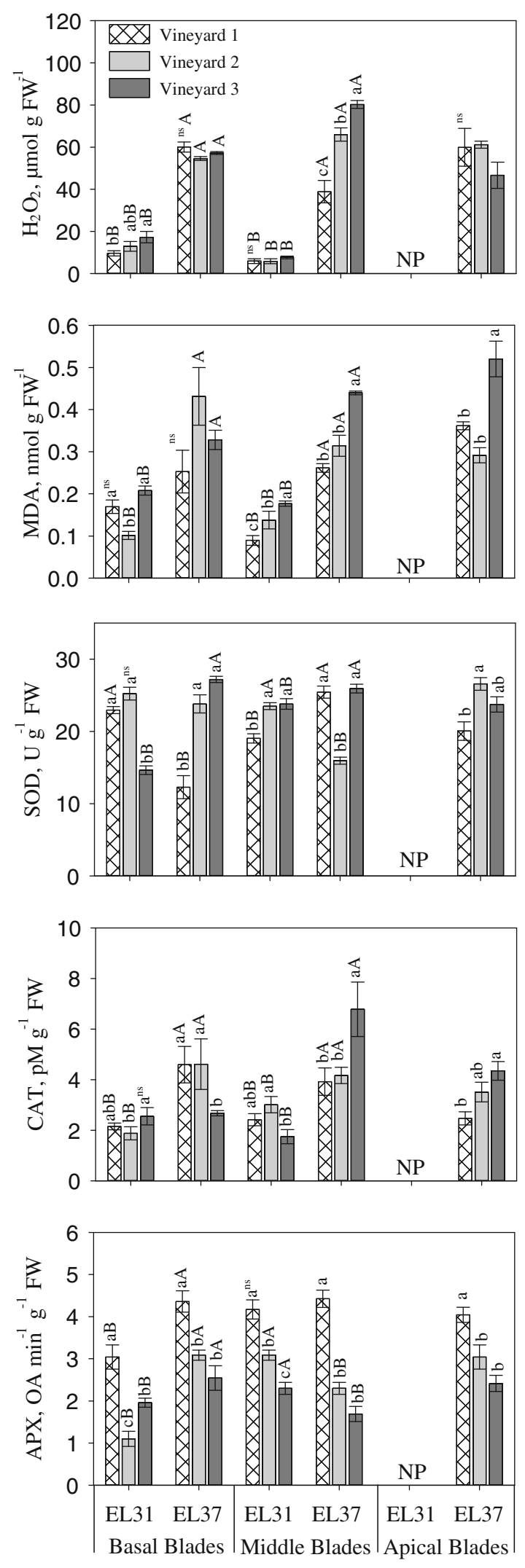
CONAMA 2009). In Australia and New Zealand, a Cu concentration of $60 \mathrm{mg} \mathrm{kg}^{-1}$ in soils necessitates studies of the effect on the environment (ANZECC/NHMRC 1992), whereas the European community advocates that $\mathrm{Cu}$ concentrations should be maintained between 40 and $140 \mathrm{mg} \mathrm{kg}^{-1}$ in soils with a $\mathrm{pH}$ below 7.0 (Council Directive 86/278/EEC 1986). However, the low concentration of clay and organic matter found in the soils used in this study caused a low sorption capacity (Bradl 2004) and, therefore, a high $\mathrm{Cu}$ availability (Table 2). This phenomenon has been reported in other studies of vineyards containing acid and sandy soils and occurs because an acidic $\mathrm{pH}$ is one of the most important factors contributing to increased $\mathrm{Cu}$ toxicity in soils (Brun et al. 1998; Pietrzak and McPhail 2004).

The CuA extraction method using EDTA is frequently used to evaluate the $\mathrm{Cu}$ availability to plants. In the vineyard soils used in this study, the EDTA extraction method demonstrated a high availability of accumulated $\mathrm{Cu}_{\mathrm{T}}$. In $\mathrm{VN} 3$, the concentrations of $\mathrm{Cu}_{\mathrm{A}}$ were up to 120 times higher than the concentration required by the plants, which is $0.5 \mathrm{mg} \mathrm{kg}^{-1}$ (CQFS$\mathrm{RS} / \mathrm{SC} 2004$ ), and these high levels can be toxic to grapevines. In other grapevine soils, it has been reported that in soils of an acidic nature and in limestone soils, the EDTA extracts between $10 \%$ and $50 \%$ of the total $\mathrm{Cu}$ and frequently demonstrates concentrations between 20 and $60 \mathrm{mg} \mathrm{kg}^{-1}$ (Brun et al. 1998; Chaignon and Hinsinger 2003). This behavior is consistent with the $\mathrm{Cu}_{\mathrm{A}}$ concentrations observed in this study.

Moreover, because of the naturally low $\mathrm{P}$ concentrations in the soils used in this study, the addition of Pcontaining fertilizers resulted in high $\mathrm{P}$ availability (Table 2). Phosphorus is a major limiting factor for the growth of plants in soils contaminated with $\mathrm{Cu}$ (Nikolic et al. 2011) and has been used to mitigate toxicity (Cao et al. 2003). However, in recent years, organic fungicides containing $\mathrm{Zn}$ salts, such as Mancozeb, have replaced Cu-based fungicides. The frequent use of these fungicides may have increased the concentrations of $\mathrm{Zn}$ in the soils (Fernández-Calviño et al. 2012), which explains the $\mathrm{Zn}$ concentration observed in VN3 (Table 2).

\section{$\mathrm{Cu}$ concentration and content in grapevines}

The $\mathrm{Cu}$ accumulation in the roots of plants grown in the tested soils was consistent with reports in the literature, and $\mathrm{Cu}$ accumulation was observed in young grapevines cultivated in soils contaminated with $\mathrm{Cu}$ (Toselli et al. 2009). In this study, the increasing $\mathrm{Cu}$ concentrations in the soil did not affect the concentration in roots of the grapevines during the productive season (Fig. 2, Table 2). This behavior may have occurred because at the evaluation stage, the annual young roots, which were smaller in diameter, were present in smaller quantities, whereas the thicker and lignified roots prevailed. Copper may have accumulated in the fine roots that are produced annually and are more active at absorbing nutrients. However, these roots have a short lifespan and are renewed every year (Anderson et al. 2003), which results in the elimination of the $\mathrm{Cu}$ they have accumulated. Moreover, although the thicker and suberized roots contribute very little to the absorption of nutrients, they are involved mainly in the translocation of water and nutrients, and they store carbohydrates and nutrients (Eissenstat 2007). However, compared with the DM found in the stems, shoots and leaves, the amount of DM in the roots was relatively high (Fig. 2). Therefore, even with $\mathrm{Cu}$ concentrations of $\sim 15 \mathrm{mg} \mathrm{kg}^{-1}$, the roots were the grapevine organ that contained the highest amount of $\mathrm{Cu}$.

The main role of the stems is to support the branches and to serve as an organ that transports water and nutrients between the roots and the aerial parts of the plant. Our data demonstrated that the $\mathrm{Cu}$ concentration in the stems of the grapevines was not affected by the increased availability of the metal in the soil. In addition, the lowest $\mathrm{Cu}$ concentrations were observed in the stems of the VN3 grapevines, which exhibited the highest $\mathrm{Cu}$ concentration in the soil. These data can be explained by the dilution of the $\mathrm{Cu}$ accumulated in the DM of the stems, which was higher in the VN2 and VN3 plants (Fig. 2, Table 3). In contrast, even compared with the other organs, the stems with the lowest concentrations of $\mathrm{Cu}$ exhibited the second highest value for the cumulative amount because of the higher DM (Fig. 2). Our data are inconsistent with a report by Lai et al. (2010), which demonstrated high Cu concentrations (ranging from 200 to $600 \mathrm{mg} \mathrm{kg}^{-1} \mathrm{DM}$ ) in the perennial organs of grapevines grown in soil containing total $\mathrm{Cu}$ concentrations that were similar to the levels observed in this study (an average of $\sim 20$ to $\sim 60 \mathrm{mg} \mathrm{kg}^{-1}$ in the $0.00-0.20$ m layer).

The $\mathrm{Cu}$ concentrations in the shoots in both cycles studied were also affected little by the concentrations of $\mathrm{Cu}_{\mathrm{T}}$ or $\mathrm{Cu}_{\mathrm{A}}$ in the soil. A positive correlation between the $\mathrm{Cu}$ concentrations in the shoots and the concentrations in 
the soil was observed only at stage EL17 in the 2010/2011 cycle (Fig. 3, Table 3). However, the results obtained in the 2009/2010 cycle suggested that at the early stages after the start of sprouting, the concentrations in the shoots were related to the $\mathrm{Cu}$ concentration in the stems of the grapevines at stages EL09 and EL19 (Fig. 2). A likely explanation for this observation is that in the early stages of growth, the shoots are tender and maintain a relationship with the stem and the stem $\mathrm{Cu}$ concentrations. In the advanced stages, there was a significant increase in DM (Fig. 2) and lignification of tissues and an increase in transpiration because of the increased number of leaves. At this time, the $\mathrm{Cu}$ concentration was less affected by the initial $\mathrm{Cu}$ level (Figs. 2 and 3).

Similar to the stems, the shoots allow the passage of water and nutrients between the stem and the leaves and bunches. The $\mathrm{Cu}$ concentration in the shoots tends to decrease during the vegetative cycle of grapevines because they grow quickly and change from a tender structure that is more metabolically active at the early sprouting stage into a semi-hardwood structure at the end of the cycle. The application of $\mathrm{Cu}$-based fungicides increased the $\mathrm{Cu}$ concentration in the shoots of the grapevines and may have been the main contributing factor to the increase observed at stage EL31 in the 2009/2010 cycle and the variations observed in the EL31 stage in the 2010/2011 cycle. However, the increase in $\mathrm{Cu}$ concentrations in the shoots due to the applications of $\mathrm{Cu}$-based fungicides was lower than that observed in the leaves (Figs. 2 and 3). This phenomenon can be attributed to the lower surface area of the shoots compared with the leaves and the dilution of the nutrients in the DM. The data obtained in this study were inconsistent with the data obtained by Lai et al. (2010), which demonstrated that the $\mathrm{Cu}$ concentrations in the shoots of grapevines grown in conventional and organic systems ranged between $\sim 100$ and $200 \mathrm{mg} \mathrm{kg}^{-1} \mathrm{DM}$. The observed $\mathrm{Cu}$ concentration may result because in the organic system, $\mathrm{Cu}$ is the main fungicide used and can be adsorbed in plant tissues even after washing with water. Studies performed in grapevines and pear trees grown in pots demonstrated that the $\mathrm{Cu}$ concentrations in the soil do not correlate with the $\mathrm{Cu}$ concentrations in the shoots (Toselli et al. 2008, 2009).

The bunches of grapes are clearly visible from stage EL12 (between five and six leaves are unfolded); however, the highest increase in dry matter and nutrient demand begins only with the emergence of the berries (EL29, small berries) (Eichhorn and Lorenz 1977).
This study demonstrated that the $\mathrm{Cu}$ concentration in the bunches did not correlate with the $\mathrm{Cu}$ concentration in the soil and that the use of $\mathrm{Cu}$-based fungicides increased the $\mathrm{Cu}$ concentrations in the bunches, particularly in the rachis (Figs. 2 and 3, Table 3). However, even after the growth of the berries and the consequent accumulation of nutrients from the soil and from various parts of the plant, the $\mathrm{Cu}$ concentration remained close to $20 \mathrm{mg} \mathrm{kg}^{-1} \mathrm{DM}$ (which is approximately 4$5 \mathrm{mg} \mathrm{kg}^{-1}$ fresh weight (FW)) for the three vineyards. Li (1994) reported that in vineyards using Cu-based fungicides, extremely high $\mathrm{Cu}$ concentrations were observed in the leaves and petioles of the grapevines (all $>118 \mathrm{mg} \mathrm{kg}^{-1}$ ), whereas the concentrations in the pulp of the berries (skin and seeds removed) ranged from 0.33 to $1.7 \mathrm{mg} \mathrm{kg}^{-1} \mathrm{FW}$. García-Esparza et al. (2006) demonstrated that the amount of $\mathrm{Cu}$ applied via fungicides exhibited a low correlation $\left(R^{2}=0.26\right)$ with the metal residues in the grapes. The same study reported $\mathrm{Cu}$ concentrations in grapes ranging from 2 to $40 \mathrm{mg} \mathrm{kg}^{-1} \mathrm{FW}$, and after 50 days of fungicide application, the concentrations decreased to values below $10 \mathrm{mg} \mathrm{kg}^{-1} \mathrm{FW}$. These results can be attributed to the smaller surface area of the berries compared to the leaves and their natural waxy coating that prevents the accumulation of the $\mathrm{Cu}$ from the fungicides.

Studies performed under field conditions generally report high $\mathrm{Cu}$ concentrations in the leaves of grapevines. Pinamonti et al. (1999) reported $\mathrm{Cu}$ concentrations close to $270 \mathrm{mg} \mathrm{kg}^{-1}$ in the leaves of grapevines cultivated in soils contaminated by the addition of organic compounds. Higher concentrations of $\mathrm{Cu}$ were found by Lai et al. (2010) in grapevines cultivated in organic or conventional systems and observed concentrations of 400 $1600 \mathrm{mg} \mathrm{kg}^{-1}$ in the leaves of the grapevines. Similarly, $\mathrm{Li}$ (1994) reported $\mathrm{Cu}$ concentrations between 118 and $9845 \mathrm{mg} \mathrm{kg}^{-1}$ in the petioles and leaves of grapevines grown in soils with an accumulation of $\mathrm{Cu}$. In contrast, Toselli et al. (2009) reported that in grapevines grown in pots containing soil with up to $1,000 \mathrm{mg} \mathrm{kg}^{-1} \mathrm{Cu}$, reduced plant growth and chlorosis of the leaves was observed with $\mathrm{Cu}$ concentrations between 10 and $20 \mathrm{mg} \mathrm{kg}^{-1}$. The data obtained in this study demonstrated that the concentrations of $\mathrm{Cu}$ in the leaves effectively originated from the $\mathrm{Cu}$ in the soil at a concentration ranging from 7 to $10 \mathrm{mg} \mathrm{kg}^{-1}$; however, levels up to $25 \mathrm{mg} \mathrm{kg}^{-1}$ were found in the leaf blades in response to increased concentrations of $\mathrm{Cu}$ in the soil (Figs. 2 and 3). In spite of this correlation with the $\mathrm{Cu}$ concentrations in 
the soil, the $\mathrm{Cu}$ concentration and content in the leaves was weak and represented a small fraction of the $\mathrm{Cu}$ content of the plants. However, after the application of $\mathrm{Cu}$-based fungicides, the concentrations in the leaves increased several-fold, reaching concentrations higher than the concentrations found in the soil. This observation can be explained by the fact that the $\mathrm{Cu}$ applied via the fungicide was absorbed by the apoplast of the leaves and was not removed by washing the plant with water, which has also been reported by Li (1994). Because of their smaller surface area, the petioles of the leaves in the grapevines were less contaminated by spraying with the $\mathrm{Cu}$-based fungicides and demonstrated $\mathrm{Cu}$ concentrations that were several times lower than observed in the leaf blades. The petiole nutrient concentrations are related to the concentration in the leaves, and this concentration is used to diagnose the nutritional status of grapevines (CQFS-RS/SC 2004). The difference between the $\mathrm{Cu}$ concentration in the petioles and blades (Fig. 3) supported the hypothesis that the $\mathrm{Cu}$ applied via fungicide was not taken up by the plant or redistributed in the tissues.

\section{Nutritional status of the grapevines}

The toxic effects of $\mathrm{Cu}$ on the root system of plants affect the absorption of water and nutrients. Reduced root growth affects mainly the uptake of the nutrients supplied by diffusion, such as $\mathrm{K}$ and $\mathrm{P}$ (Marschner 1995), because of the reduced volume of soil explored by the smaller roots. In studies of soils contaminated with $\mathrm{Cu}$, a $\mathrm{P}$ deficiency is the most limiting factor that hinders the growth of annual plants such as wheat (Nikolic et al. 2011). Moreover, excess $\mathrm{Cu}$ also impairs nitrogen assimilation, especially in the root system, which was observed in a study of young grapevines performed by Llorens et al. (2000). However, our data demonstrated that the grapevine exhibited similar concentrations of $\mathrm{N}, \mathrm{P}, \mathrm{K}, \mathrm{Ca}$ and $\mathrm{Mg}$ in the leaf blades, indicating that the excess of $\mathrm{Cu}$ in the soil did not affect the uptake of these nutrients. During the productive season, grapevines exhibit a broad and deep root system and may take up nutrients from soil layers with lower $\mathrm{Cu}$ levels. In addition, constant fertilization performed to maintain soil fertility increases the availability of nutrients in the soil, therefore mitigating the toxic effects of $\mathrm{Cu}$ through better plant nutrition (Marschner 1995). The toxic effects of $\mathrm{Cu}$ in the roots also reduce the absorption of micronutrients, mainly Fe, Zn and Mn (Marschner 1995; Toselli et al. 2008,
2009). The concentration of these nutrients was not investigated in this study; however, visual symptoms of a deficiency in these nutrients were not observed.

\section{Biochemical parameters in leaf blades}

The excessive formation of ROS results from an imbalance in electron flow in oxidation-reduction reactions in the presence of excessive concentrations of $\mathrm{Cu}$, $\mathrm{Fe}, \mathrm{Zn}$ and other metals and factors (Apel and Hirt 2004). These oxidation-reduction reactions occur mostly in the peroxisomes and mitochondria and particularly in the chloroplasts in photosynthetic organs (Dat et al. 2000). Under conditions of oxidative stress, increased concentrations of $\mathrm{H}_{2} \mathrm{O}_{2}$ and other ROS are observed, leading to lipid peroxidation, which results from the attack of the hydrogens in fatty acid chains and the consequent formation of lipid radicals and aldehydes (Apel and Hirt 2004). Lipid peroxidation, estimated by the MDA concentration, is an important parameter for assessing cell damage because of the toxic effects of heavy metals (Islam et al. 2008; Yang et al. 2011). In this study, the leaf blades exposed to direct insolation exhibited higher lipid peroxidation. Changes were also observed in the concentration of $\mathrm{H}_{2} \mathrm{O}_{2}$ and in the activity of CAT and APX. This condition was observed mainly in the $\mathrm{BB}$ and $\mathrm{MB}$ at stage EL31 and in the MB and AB at stage EL37 (Fig. 4). This phenomenon was related to the growth of the shoots and the emergence of new leaves, with consequent shading of the basal leaves. The changes in the cellular metabolism of the leaf blades directly exposed to solar radiation correlated with the excessive $\mathrm{Cu}$ in soils (data not shown) and were not related to the $\mathrm{Cu}$ concentrations in the leaves, which were mostly caused by the application of Cu-based fungicides (Figs. 2 and 3). After the fungicide applications, the highest concentrations of $\mathrm{Cu}$ in the leaves of the grapevines were observed in VN1, which had the lowest concentration of the metal in the soil and MDA in the leaf blades. These results suggested that the $\mathrm{Cu}$ applied via fungicide did not affect the cellular metabolism. Therefore, the $\mathrm{Cu}$ can remain in the apoplast of the leaves or in other organs. However, increased concentrations of $\mathrm{Cu}$ in the leaves because of an excess of the metal in the soil (observed at stage EL19 in the 2009/2010 cycle; and at stage EL17 in the 2010/2011 cycle) could be the main factor contributing to the changes in metabolism and the increased MDA. 
In our study, the concentration of MDA in the MB and $\mathrm{AB}$ was consistently higher in VN3 (Fig. 4), which demonstrated the highest concentrations of $\mathrm{Cu}$ in the soil (Fig. 4, Table 2). However, the $\mathrm{H}_{2} \mathrm{O}_{2}$ concentrations were higher in VN3 only in the BB at stage EL31 and especially in the MB at stage EL37. SOD, CAT and APX are important key enzymes in the removal of ROS (Apel and Hirt 2004), and the activities of these enzymes are generally increased under conditions of high levels of metals (Zhang et al. 2010). However, in this study, the SOD activity was variable and was explained partially by the concentrations of $\mathrm{H}_{2} \mathrm{O}_{2}$ or $\mathrm{Cu}$ in the soil and leaves. In addition, the concentration of $\mathrm{H}_{2} \mathrm{O}_{2}$ between stages EL31 and EL37 increased more than three-fold, likely because of the older leaves, without a corresponding increase in SOD activity (Fig. 4). Yang et al. (2011) also observed no changes in SOD activity in grapevines grown with an excess of $\mathrm{Zn}$ in soil. Excess $\mathrm{Cu}$ in cells can differently affect the activity of the SOD isoforms in the cytoplasm, chloroplasts, mitochondria and peroxisomes (Møller et al. 2007), which were not evaluated separately in this study. The formation of $\mathrm{H}_{2} \mathrm{O}_{2}$ from $\mathrm{O}^{2 .-}$ can also be catalyzed by transition metals, such as $\mathrm{Fe}^{3+}$ and $\mathrm{Cu}^{2+}$, via the Fenton reaction (Møller et al. 2007), without requiring enzymes.

The increased CAT activity observed at stage EL37 in the $\mathrm{MB}$ and $\mathrm{AB}$ also coincided with the full exposure of the leaves to the sun; however, this effect was not observed at stage EL31 when the leaves were younger. CAT has high affinity for $\mathrm{H}_{2} \mathrm{O}_{2}$ (mM range) and catalyzes the direct conversion of $\mathrm{H}_{2} \mathrm{O}_{2}$ into $\mathrm{H}_{2} \mathrm{O}$ and $\mathrm{O}_{2}$. Because of these characteristics, an increased CAT activity is observed under conditions of oxidative stress (Dat et al. 2000; Apel and Hirt 2004). Yang et al. 2011 observed that increased $\mathrm{Zn}$ in the soil resulted first in increased CAT activity in the leaves of grapevines, followed by a sharp decrease in the CAT activity because of the high degree of toxicity. In the same study, increased concentrations of $\mathrm{Zn}$ in the soil caused the progressive reduction in peroxidase activity. This behavior was also observed in this study; the APX activity in the leaf blades was lower in VN2 and VN3, in which the highest concentrations of $\mathrm{Cu}$ in the soil were found. The reduced APX activity could have been a direct or indirect effect of the excess $\mathrm{Cu}$ on the functioning of this enzyme. APX is part of the glutathione-ascorbate cycle (Dat et al. 2000) and is very sensitive to reduced concentrations of oxidized ascorbate, which is one of its substrates (Shigeoka et al. 2002). Excessive $\mathrm{Cu}$ in cells leads to the formation of phytochelatins from glutathione and $\mathrm{SH}$ groups, which are present when these molecules are chelated (De Vos et al. 1989). This process reduces the ascorbate-glutathione cycle activity, and the lower concentrations of oxidized ascorbate reduce APX activity.

The increased MDA, $\mathrm{H}_{2} \mathrm{O}_{2}$ concentrations and changes in the CAT and APX enzymes observed in this study were indications of the effect of excess $\mathrm{Cu}$ in the mature leaves, which exhibited full photosynthetic activity. However, the damage to the leaves tended to be small because decreased vegetative vigor or chlorosis, classic symptoms of toxicity by $\mathrm{Cu}$ and other metals, were not observed in the grapevines (Marschner 1995; Toselli et al. 2009; Yang et al. 2011). Additionally, the excellent nutritional status of the plants and the satisfactory production of grapes in these vineyards indicated that the adult grapevines were tolerant to the excess $\mathrm{Cu}$ in the soil.

\section{Conclusion}

The increased $\mathrm{Cu}$ concentrations observed in the leaves and the evidence of oxidative stress correlated with the increased $\mathrm{Cu}$ concentrations in the soil. However, the increased $\mathrm{Cu}$ availability in the soils only slightly affected the concentrations and accumulation of $\mathrm{Cu}$ in the grapevines during the productive season and did not change the nutritional status of the plants. The use of $\mathrm{Cu}$-based fungicides was the main determinant for the increased $\mathrm{Cu}$ concentrations in the annual organs of the grapevines, especially in the leaves and rachis; however, the residual $\mathrm{Cu}$ in the berries was not related to the amount of $\mathrm{Cu}$ applied.

Acknowledgments We are grateful to FAPERGS, the CNPq and CAPES for the scholarships provided and the financial resources made available for this study. We are also grateful to the Almadén Wine Company for making the experimental vineyards available.

Open Access This article is distributed under the terms of the Creative Commons Attribution License which permits any use, distribution, and reproduction in any medium, provided the original author(s) and the source are credited.

\section{References}

Aebi H (1984) Catalase: in vitro. Methods Enzymol 105:121-126 Anderson LJ, Comas LH, Lakso AN, Eissenstat DM (2003) Multiple risk factors in root survivorship: a 4-year study in Concord grape. New Phytol 158:489-501. doi:10.1046/j. 1469-8137.2003.00757.x 
ANZECC/NHMRC (Australian and New Zealand Environment and Conservation Council, National Health and Medical Research Council) (1992) Australian and New Zealand guidelines for the assessment and management of contaminated sites

Apel K, Hirt H (2004) Reactiven oxygen species: Metabolism, oxidative Stress, and signal transduction. An Rev Plant Biol 55:373-C-372. doi:10.1146/annurev.arplant.55.031903.141701

Arias M, López E, Fernández D, Soto B (2004) Copper distribution and dynamics in acid vineyard soils treated with copper-based fungicides. Soil Sci 169:796-805

Arias M, Pérez-Novo C, Osorio F, López E, Soto B (2005) Adsorption and desorption of copper and zinc in the surf ace layer of acid soils. J Colloid Interf Sci 288:21-29. doi:10.1016/j.jcis.2005.02.053

Bradl HB (2004) Adsorption of heavy metal ions on soils and soils constituents. Colloid Interf Sci 27:1-18. doi:10.1146/ annurev.arplant.55.031903.141701

Brun LA, Maillet J, Richarte J, Herrmann P, Rémy JC (1998) Relationships between extractable copper, soil properties and copper uptake by wild plants in vineyard soils. Environ Pollut 102:151-161. doi:10.1016/s0269-7491(98)00120-1

Brun LA, Maillet J, Hinsinger P, Pépin M (2001) Evaluation of copper availability to plants in copper-contaminated vineyard soils. Environ Pollut 111:293-302. doi:10.1016/ S0269-7491(00)00067-1

Brun LA, Corff JLE, Maillet J (2003) Effects of elevated soil copper on henology, growth and reproduction of five ruderal plant species. Environ Pollut 122:361-368. doi:10.1016/ S0269-7491(02)00312-3

Cao RX, Lena LQ, Chen M, Singh SP, Harris WG (2003) Phosphateinduced metal immobilization in a contaminated site. Environ Pollut 122:19-28. doi:10.1016/S0269-7491(02)00283-X

Casali CA, Moterle DF, Rheinheimer DS, Brunetto G, Mello ALC, Kaminski J, Melo GWB (2008) Formas e dessorção de cobre em solos cultivados com videira na Serra Gaúcha do Rio Grande do Sul. Rev Bras Ciênc Solo 32:1479-1487. doi:10.1590/S0100-06832008000400012

CETESB (Companhia de Tecnologia de Saneamento Ambiental) (2005) Decisão de Diretoria No 195-2005- E, 23/11/2005. Dispõe sobre a aprovação dos valores orientadores para solos e águas subterrâneas no Estado de São Paulo, em substituição aos valores orientadores de 2001, e dá outras providências. (In Portuguese.) Governo do Estado de São Paulo, São Paulo

Chaignon V, Hinsinger P (2003) A biotest for evaluating copper bioavailability to plants in a contaminated soil. J Enviro Qual 32:824-833. doi:10.2134/jeq2003.8240

Chaignon V, Quesnoit M, Hinsinger P (2009) Copper availability and bioavailability are controlled by rhizosphere $\mathrm{pH}$ in rape grown in an acidic Cu-contaminated soil. Environ Pollut 157:3363-3369. doi:10.1016/j.envpol.2009.06.032

CONAMA (Conselho Nacional do Meio Ambiente) (2009) Resolução 420, de 28/12/2009 Dispõe sobre critérios e valores orientadores de qualidade do solo quanto à presença de substâncias químicas e estabelece diretrizes para o gerenciamento ambiental de áreas contaminadas por essas substâncias em decorrência de atividades antrópicas. Diário Oficial da Repúbica Federativa do Brasil, 249, Brasília

Council Regulation 2092/91/EEC (1991) of 24 June 1991 on organic production of agricultural products and indications referring thereto on agricultural products and foodstuffs. Off J L, 198, Anexo II

Council Directive 86/278/EEC (1986) Protection of the environment, and in particular of the soil, when sewage sludge is used in agriculture. Off J Eur Union 181

CQFS RS/SC (Comissão de Química e Fertilidade do Solo - RS/SC) (2004) Manual de adubação e calagem para os Estados do Rio Grande do Sul e Santa Catarina. Núcleo Regional Sul Sociedade Brasileira de Ciência do Solo, Porto Alegre, p 400

Dat J, Vandenabeele S, Vranová E, Van Montagu M, Inzé D, Van Breusegem F (2000) Dual action of the active oxygen species during plant stress responses. Cell Mol Life Sci 57:779-795. doi:10.1007/s000180050041

De Vos CHR, Schat H, Vooijs R, Ernst WHO (1989) Copper induced damage to the permeability barrier in roots of Silene cucubalus. J Plant Physiol 135:164. doi:10.1016/ S0176-1617(89)80171-3

Dumestre A, Sauve S, McBride M, Baveye P, Berthelin J (1999) Copper speciation and microbial activity in long-term contaminated soil. Arch Environ Contant Toxicol 36:24-131. doi:10.1007/s002449900451

Eichhorn KW, Lorenz H (1977) Phaenologische Entwicklungstadiender Rebe. Nachrichtenblatt des Deutschen Pflanzenschutzdienstes 21:119-120

Eissenstat DM (2007) Dinamica di crescita delle radici nelle coltura da frutto. Italus Hortus 14:1-8

El-Moshaty FIB, Pike SM, Novacky AJ, Sehgal OP (1993) Lipid peroxidation and superoxide production in cowpea (Vigna unguiculata) leaves infected with tobacco ringspot virus or southern bean mosaic virus. Physiol Mol Plant Pathol 43:109-119. doi:10.1006/pmpp.1993.1044

Embrapa (Empresa Brasileira de Pesquisa Agropecuária), (1997) Manual de métodos de análise de solo. CNPS, Rio de Janeiro, p 212

Fernández-Calviño D, Rodríguez-Suárez JA, López-Periago E, Arias-Estévez M, Simal-Gándara J (2008) Copper content of soils and river sediments in a winegrowing area, and its distribution among soil or sediment components. Geoderma 145:91-97. doi:10.1016/j.geoderma.2008.02.011

Fernández-Calviño D, Pérez-Novo C, Nóvoa-Muñoz JC, AriasEstévez M (2009) Copper fractionation and release from soils devoted to different crops. J Hazard Mater 167:797802. doi:10.1016/j.jhazmat.2009.01.054

Fernández-Calviño D, Pateiro-Moure M, Nóvoa-Muñoz JC, Garrido-Rodríguez B, Arias-Estévez M (2012) Zinc distribution and acid-base mobilisation in vineyard soil and sediments. Sci Total Environ 414:470-479. doi:10.1016/j. scitotenv.2011.10.033

García-Esparza MA, Capria E, Pirzadeha P, Trevisana M (2006) Copper content of grape and wine from Italian farms. Food Addit Contam. doi:10.1080/02652030500429117

IPA - Instituto de Pesquisas Agronômicas (1989) Atlas Agroclimático do Estado do Rio Grande do Sul. Porto Alegre. http://www.cpact.embrapa.br/agromet/tab/tabela19. html. Accessed 05 June 2012

Islam E, Liu D, Li T, Yang X, Jin X, Mahmood Q, Tian S, Li J (2008) Effect of $\mathrm{Pb}$ toxicity on leaf growth, physiology and ultrastructure in the two ecotypes of Elsholtzia argyi. J Hazard Mater 154:914-926. doi:10.1016/j.jhazmat.2007. 10.121

Komárek M, Cadková E, Chrastný V, Bordas F, Bollinger JC (2010) Contamination of vineyard soils with fungicides: a 
review of environmental and toxicological aspects. Enviro Int 36:138-151. doi:10.1016/j.envint.2009.10.005

Kopsell DE, Kopsell DA (2007) Copper. In: Barker AV, Pilbeam DJ (eds) Handbook of plant nutrition. Boca Raton, Taylor and Francis Group, pp 293-328

Lai H-Y, Juang K-W, Chen BC (2010) Copper concentrations in grapevines and vineyard soils in central Taiwan. Soil Sci Plant Nutr 56:601-606. doi:10.1111/j.1747-0765.2010.00494

Li R (1994) Effect of long-term applications of copper on soil and grape copper (Vitis vinifera). Can J Soil Sci 74:345347. doi:10.4141/cjss94-047

Llorens N, Arola L, Blade C, Mas A (2000) Effects of copper exposure upon nitrogen metabolism in tissue cultured Vitis vinifera. Plant Sci 160:159-163. doi:10.1016/S0168-9452(00)00379-4

Loreto F, Velikova V (2001) Isoprene produced by leaves protects the photosynthetic apparatus against ozone damage, quenches ozone products, and reduces lipid peroxidation of cellular membranes. Plant Physiol 127:1781-1787. doi:10. 1104/pp. 010497

Marschner H (1995) Mineral Nutrition of Higher Plants. Academic, San Diego

Misra HP, Fridovich I (1972) The role of superoxide anion in the autoxidation of epinephrine and a simple assay for superoxide dismutase. J Biol Chem 247:3170-3175

Møller LM, Jensen PE, Hansson A (2007) Oxidative modifications to cellular components in plants. Ann Rev Plant Biol 58:459481. doi:10.1146/annurev.arplant.58.032806.103946

Nikolic N, Kostic L, Djordjevic A, Nikolic M (2011) Phosphorus deficiency is the major limiting factor for wheat on alluvium polluted by the copper mine pyrite tailings: a black box approach. Plant and Soil 339:485-498. doi:10.1007/ s11104-010-0605-x

Pietrzak U, McPhail DC (2004) Copper accumulation, distribution and fractionation in vineyard soils of Victoria, Australia. Geoderma 122:151-166. doi:10.1016/j.geoderma.2004.01.005

Pinamonti F, Nicolini G, Dalpiaz A, Stringari G, Zorzi G (1999) Compost use in viticulture: effect on heavy metal levels in Soil and plants. Commun Soil Sci Plant Anal 30:1531-1549

Robinson B, Greven M, Green S, Sivakumaran S, Davidson P, Clothier B (2006) Leaching of copper, chromium and arsenic from treated vineyard posts in Marlborough, New
Zealand. Sci Total Environ 364:113-123. doi:10.1016/j. scitotenv.2005.07.012

Shigeoka S, Ishikawa T, Tamoi M, Miyagawa Y, Takeda T, Yabuta Y, Yoshimura K (2002) Regulation and function of ascorbate peroxidase isoenzymes. J Exp Bot 53:13051319. doi:10.1093/jexbot/53.372.1305

SSS (Soil Survey Staff) (2010) Soil Taxonomy Agricultural Handbook. United States Department of Agriculture, Washington

Tedesco MJ, Gianello C, Bissani C, Bohnen H, Volkweiss SJ (1995) Análise de solo, plantas e outros materiais. UFRGS/ FA/DS, Porto Alegre, p 174, Boletim técnico 5

Toselli M, Baldi E, Marcolini G, Malaguti D, Marangoni B, Quartieri M (2008) Response of potted pear trees to increasing copper concentration in sandy and clay-loam soils. J Plant Nutr 2089-2104 doi:10.1080/01904160802459609

Toselli M, Baldi E, Marcolini G, Malaguti D, Quartieri M, Sorrenti G, Marangoni B (2009) Response of potted grapevines to increasing soil concntation. Aust J Grape Wine Res 15:85-92. doi:10.1111/j.1755-0238.2008.00040.x

USEPA (United States Environmental Protection Agency) (1996) Method 3050B. Acid digestion of sediments, sludges, and soils. Revision 2, Washington

Yang Y, Sun C, Yao Y, Zhang Y, Achal V (2011) Growth and physiological responses of grape (Vitis vinifera "Combier") to excess zinc. Acta Physiologiae Plantarum 33:14831491. doi:10.1007/s11738-010-0687-3

Yruela I (2005) Copper in plants. Braz J Plant Physiol 17:145156. doi:10.1590/S1677-04202005000100012

Yruela I, Alfonso M, Barón M, Picorel R (2000) Copper effect on the protein composition of photosystem II. Physiol Plant 110:551-557. doi:10.1111/j.1399-3054.2000.1100419.x

Zhang H, Zhang F, Xia Y, Wang G, Shen Z (2010) Excess copper induces production of hydrogen peroxide in the leaf of Elsholtzia haichowensis through apoplastic and symplastic CuZn-superoxide dismutase. J Hazard Mater 178:834-843. doi:10.1016/j.jhazmat.2010.02.014

Zhu Z, Wei G, Li J, Qian Q, Yu J (2004) Silicon alleviates salt stress and increases antioxidant enzymes activity in leaves of salt-stressed cucumber (Cucumis sativus L.). Plant Sci 167:527-533. doi:10.1016/j.plantsci.2004.04.020 